\title{
Review \\ A Critical Review of Supersonic Flow Control for High-Speed Applications
}

\author{
Abdul Aabid ${ }^{1, *(\mathbb{D})}$, Sher Afghan Khan ${ }^{2}$ and Muneer Baig ${ }^{1}(\mathbb{D}$ \\ 1 Department of Engineering Management, College of Engineering, Prince Sultan University, P.O. Box 66833, \\ Riyadh 11586, Saudi Arabia; mbaig@psu.edu.sa \\ 2 Department of Mechanical Engineering, Faculty of Engineering, International Islamic University Malaysia, \\ Kuala Lumpur 50728, Malaysia; sakhan06@gmail.com \\ * Correspondence: aaabid@psu.edu.sa or aabidhussain.ae@gmail.com
}

Citation: Aabid, A.; Khan, S.A.; Baig M. A Critical Review of Supersonic Flow Control for High-Speed Applications. Appl. Sci. 2021, 11, 6899 https://doi.org/10.3390/ app11156899

Academic Editors: Luís L. Ferrás and Alexandre M. Afonso

Received: 26 June 2021

Accepted: 21 July 2021

Published: 27 July 2021

Publisher's Note: MDPI stays neutral with regard to jurisdictional claims in published maps and institutional affiliations.

Copyright: (c) 2021 by the authors. Licensee MDPI, Basel, Switzerland. This article is an open access article distributed under the terms and conditions of the Creative Commons Attribution (CC BY) license (https:/ / creativecommons.org/licenses/by/ $4.0 /)$.

\begin{abstract}
In high-speed fluid dynamics, base pressure controls find many engineering applications, such as in the automobile and defense industries. Several studies have been reported on flow control with sudden expansion duct. Passive control was found to be more beneficial in the last four decades and is used in devices such as cavities, ribs, aerospikes, etc., but these need additional control mechanics and objects to control the flow. Therefore, in the last two decades, the active control method has been used via a microjet controller at the base region of the suddenly expanded duct of the convergent-divergent (CD) nozzle to control the flow, which was found to be a costefficient and energy-saving method. Hence, in this paper, a systemic literature review is conducted to investigate the research gap by reviewing the exhaustive work on the active control of high-speed aerodynamic flows from the nozzle as the major focus. Additionally, a basic idea about the nozzle and its configuration is discussed, and the passive control method for the control of flow, jet and noise are represented in order to investigate the existing contributions in supersonic speed applications. A critical review of the last two decades considering the challenges and limitations in this field is expressed. As a contribution, some major and minor gaps are introduced, and we plot the research trends in this field. As a result, this review can serve as guidance and an opportunity for scholars who want to use an active control approach via microjets for supersonic flow problems.
\end{abstract}

Keywords: flow control; de Laval nozzle; CD nozzle; microjet; supersonic flow; CFD; DOE

\section{Introduction}

In supersonic vehicles, the flow of exit from the rockets and missile engines has become a significant issue. It has been found that the loss of air inside the high-speed vehicle engines turns to increase the base drag. For example, a nozzle with sudden expansion ducts will form a recirculation zone, increasing base drag. When the base drag increases, the total amount of exit pressure will decrease, and this decrement will result in the loss of the forwarding force or thrust. Hence, many studies have reported controlling the high-speed flows as a passive and active control method. In a passive control method, the duct shape is modified with additional devices/shapes, such as ribs, cavities, cylinders, aerospikes, splitter plate, etc. In addition, researchers used different devices of flow formation, such as a nozzle as internal flow control and bluff body, non-circular cylinders, airfoil, and wings as external aerodynamics flow control. On the other hand, the active control of high-speed flow has been studied extensively over the last two decades. Researchers have used a high-speed nozzle with a sudden expansion duct and a microjet controller; a tiny hole in the base area is drilled to control the flow, which was found to be an excellent technique in a supersonic flow problem. Hence, this review is more focused on the active control approach, using a microjet in a CD nozzle.

The abrupt expansion of the external compressible flow over the back of the projectiles and its association to the base pressure has long been the focus of researchers' interest. The 
base drag, which accounts for a significant portion of the overall drag, is determined by the base pressure. Generally, the base pressure for a high-speed projectile is lower than the ambient pressure. The vast majority of the ballistics test data were supplied, leading us to presume that the base pressure ratio depends entirely on the flight Mach number. Compared to traditional ballistics testing processes, the experimental investigation of the internal flow apparatus provides several distinguishing benefits. A significant amount of air supply is lowered, which would generally be necessary for the wind tunnel test section to be large enough so that wall interference and other factors do not disrupt the model flow. Internal flows are free of stings and other support devices that are necessary for external flow investigations. The most significant benefit of the internal flow device is that static pressure and surface temperature measurements can be recorded as well as the entry to the expansion and the wake zone (Figure 1). These observations are crucial if the theoretical predictions are to be extensively investigated.

The sudden expansion problems in the subsonic and supersonic flow regimes are found in many applications. We discovered that previous researchers used a system to replicate high altitude conditions in jet and rocket engine test cells, jet discharge results in insufficient, sub-atmospheric discharge pressure. This was found by Khan et al. [1], who used microjets to control the sudden expansion flow (base pressure) from the CD nozzle as an active control method.

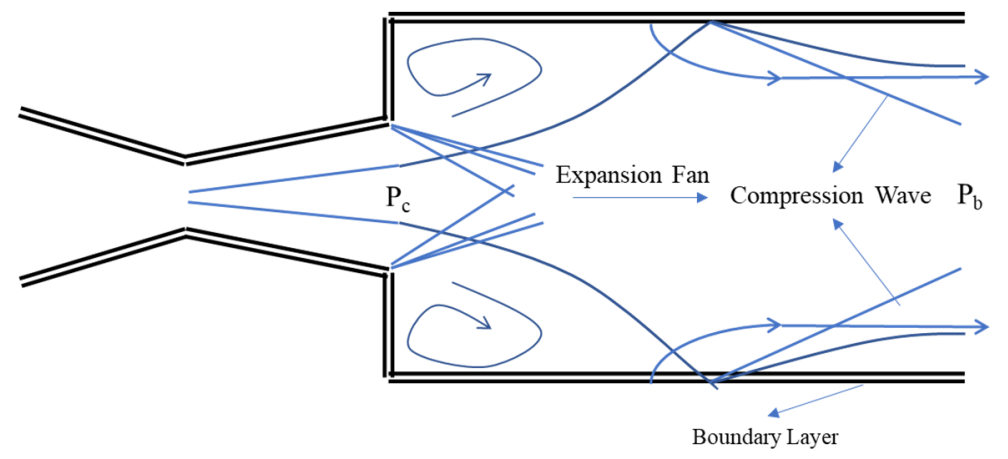

Figure 1. Sudden expansion flow field. Reprinted with permission from ref. [2]. Copyright 2021 Springer.

In this review, the following section explores the fundamental idea about flow development and its types, which gives a basic understanding of this work. Section three illustrates selected studies on the passive control method of high-speed flow, jet, and noise, which provides information about the passive devices and their benefits. Section four is the main objective of this work. Hence, for the detailed investigation, this is split into the different methodologies: experimental, computational fluid dynamics (CFD) and soft computing methods. We reviewed the most relevant papers related to the current work. Section five is the main contribution of this review; based on the existing data in this field, we explore and critically analyze the results. In addition, we propose some research gaps for future work and finally conclude, based on the current existing work.

\section{High-Speed Flow Development in Nozzle}

For supersonic flow development and investigations, a CD nozzle is utilized in most studies. A nozzle with no expanding part cannot produce supersonic air [3]; the flow is sonic at the throat; therefore, an asterisk denotes conditions at a sonic level. At the throat, the Mach number $=1,(\mathrm{~V}=\mathrm{a})$ and the throat area (a). Figure 2 illustrates a basic CD nozzle model [4] and the parameters with an asterisk are defined as critical values. If a high-pressure tank is connected to a pipe, then the velocity at the pipe exit changes depending on the backpressure. At any other region of the nozzle, the Mach number velocity and the local area can be derived by the continuity equation [5-7]. Even though it is possible to study one-dimensional flow behavior directly, it is only a particular case of 
two-dimensional flow. One of the known one-dimensional flow phenomena is the normal shock and formation of oblique shock waves. The occurrence of oblique shock waves in different flow fields occurs, such as flight at high Mach numbers, aircraft design, diffusers, and supersonic nozzles.

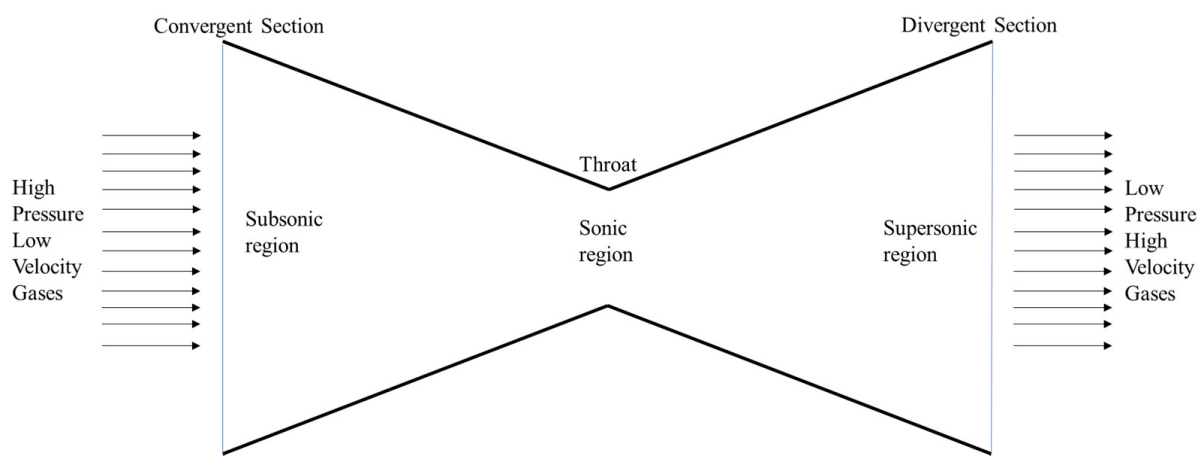

Figure 2. Convergent-divergent (CD) nozzle.

In previous studies, a particular flow rate was solved and analyzed mathematically to solve the energy equations, using a two-dimensional model of a nozzle. The measured iteration method improved the static tension, temperature, and velocity flows. The nozzle is produced and meshed with an automated technique and the sizing of the meshing processes and various values. The CD nozzle with sudden expansion was used to investigate the effect of expansion ratio for creeping expansion flows of fluid in the study of [8-11]. The CD nozzle was used to generate a supersonic flow and was simulated, using the ANSYS fluent software. The generic formula for the nozzle was determined manually, and the results were compared [3,12-14].

Nevertheless, the greatest difficulty in the CD nozzle outflow is in the subsonic and supersonic flow regimes. An abrupt expansion of the problem has various applications in the industry. In jet and rocket engine test cells, we observed that the system is used to simulate high-altitude conditions; the discharging of the jet results in inadequate discharge pressure, which is sub-atmospheric. Khan et al. [15] controlled the base pressure with the active control method, using microjets. In the active control method, the microjets were placed in the base region of the sudden expansion duct, and these microjets were directly connected to the settling chamber with the air directly passing to the duct. The inlet flow of the microjets reduced the recirculation zone, which resulted in decreasing the drag formation. A detailed study on these active flow control can be seen in Section 4 .

Usually, the fluid flows are three-dimensional; the terms one, two, or three refer to the amount of coordinated space required to demonstrate the flow. The physical motion usually tends to be three-dimensional. At the same time, these are hard to evaluate and call for the most significant possible simplification. This is done by ignoring the flow variation in any direction, thus simplifying the problem. A three-dimensional problem can be reduced to a two-dimensional one and, subsequently, can be further simplified to one-dimensional one. The continuity equation, Bernoulli's equation, and momentum equation are used to study the one-dimensional flow case as methods of solution [5,16-19]. General classification and examples of flow fields can be seen in Refs. [20,21] which provided the information of 3D flows and sediment transport models for open channel flows [20]. Chong et al. [21] classified the 3D flow, considering the first-order coupled linear differential equation, using three matrix variations for both compressible and incompressible flows. The effect of nozzle geometry on the high-velocity oxygen fuel (HVOF) system was calculated [22]; the nozzle attached inside were adjusted, and they also proved that the cold spray technique influences the HVOF system and applies to the nozzle configuration. 


\section{Passive Control Methods}

This section summarizes some of the passive control approaches of previous researchers, and it is split into three major concerns: flow, jet, and noise control, in order to extract the idea of these methods.

\subsection{Flow Control}

The examination of abrupt axi-symmetric expansion is a challenging subject that is becoming popular in a range of flow systems in the current scenario. The duct is employed with a smooth inner surface and a low base pressure in most cases. Sudden relief to the shear layer at the nozzle exit is due to the availability of a duct with a larger area. Due to a sudden increase in the duct area, the base pressure and flow-field may be articulated at the base area through the vortex dynamics produced, due to a sudden increase in the duct area. In contrast, the value of the base pressure is almost similar in the base area; however, the mean values are taken for the analysis. As a result of its wide application, abruptly increased flows have been thoroughly investigated.

The investigations were carried out in an abrupt expansion duct in several cases with passive devices such as a rib, cavity, step body, and boattail. Several studies were carried out experimentally to control the flow, and these results serve as the benchmark results. Viswanath [23] studied the impacts of riblets in pressure gradients and three-dimensionality on airfoils, wings, and wing-body combinations in different speed regimes to control the viscous drag in $3 \mathrm{M}$ riblets. Ishide and Itazawa [24] tweaked the leading edge flaps to enhance the delta wing design at a low Reynolds number of 1.9105 applied to a chord (geometric mean) of $286 \mathrm{~mm}$ as the typical length for micro and crewless air vehicles.

The flow past desired blunt-nosed body with and without spikes was tested in a primary 2D water channel, at a given Reynolds number [25], with spikes of various forms, such as conical, hemispherical, flat, and square nose. Khurana and Suzuki [26] used a forward-facing aerospike on the nose to examine the heat transfer and its control through the aerospikes for lifting the body configuration in a hypersonic flow. They used experimental techniques and a simplified model of the resulting basic symmetric-delta configuration. A similar study by the same authors [27] was carried out to assess the aerodynamic efficacy for aerospike on a hypothetical lifting-body in a hypersonic flow at various Mach numbers. In Ref. [28], the experimental research was carried out to determine the importance of the pressure hill height and the zone expansion impact for a flow-through in different forms of spikes with Reynolds numbers ranging from 2278 to 4405 to detect the vortex shedding process. In a prior work, the previous researchers [29] studied a theoretical estimate of the shock standoff distance in a supersonic range with the modified Newtonian impact theory. Based on this passive control strategy, the researchers [30] conducted the tests using a transonic wind tunnel of $38 \times 30 \mathrm{~cm}$ in the Mach number ranges of 0.7 to 1.0 and controlled the entire afterbody drag of the outlet flow. In the absence of the jet flow at the base, the same author [31] examined the development of flow management with passive control devices for the axi-symmetric base and afterbody drag reduction in different speed regimes.

Experimentally, [32] studied the control of flow in a sonic jet in a circular convergent nozzle by locating two tabs at the nozzle exit. The effects of annular ribs as a passive control device on the base pressure control was examined, using an experimental technique in a subsonic and sonic nozzle with an abrupt expansion duct [33]. In addition, the researchers investigated the pressure fluctuations in a typical missile base area design at a freestream Mach number of 0.7, with and without a base cavity [34]. The study was discovered in resonant high-speed cavity flows controlled by high frequency pulsed supersonic microjets [35] in addition to CD nozzles. A compression corner calculation model was employed to perform extensive numerical investigations in the supersonic flow field with varied injection pressure ratios, actuation locations, and nozzle types [36]. Figure 3 illustrates the different devices that were used to control the high-speed supersonic flows, particularly in a CD nozzle. 


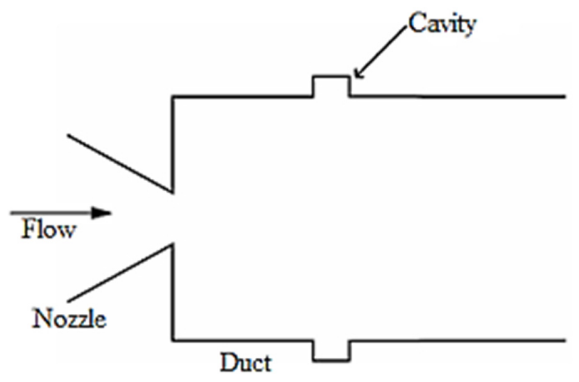

(a)

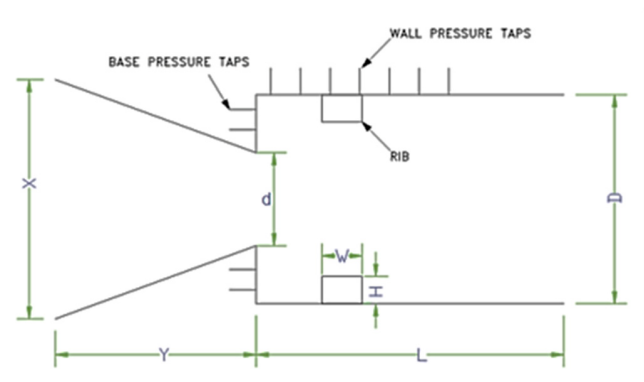

(b)

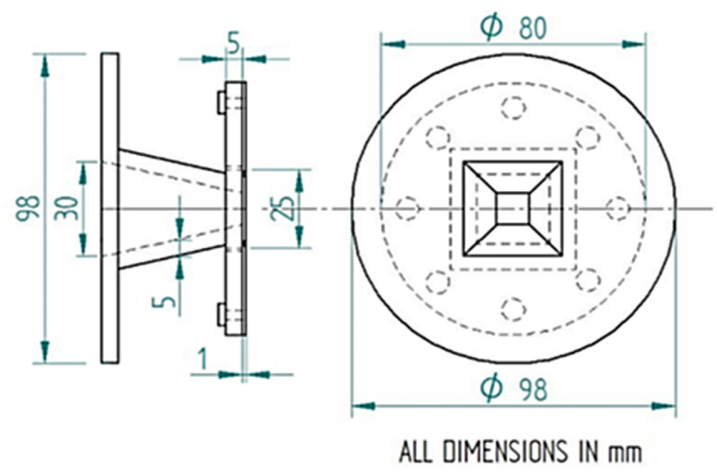

(c)

Figure 3. Passive control devices: (a) cavities [37], (b) ribs [38], and (c) cylinders [39,40]. Reprinted under the Creative Commons (CC) License (CC BY 3.0).

\subsection{Jet Control}

Mixing is required for efficient and effective jet performance in a variety of aerospace applications. Thrust vector control, missile engines, and aircraft propulsion systems are just a few of the technical applications based on jets. To manage the combustion chamber size and improve the vehicle's efficiency, effective mixing is necessary for air-breathing engines. Optimal mixing on a small and big scale is required for combustion cycles to work properly. Small-scale mixing is concerned with molecule mixing, whereas large-scale mixing is concerned with the dismantling of large-scale vortices. Acoustic radiations are caused by the existence of turbulent vortical structures and compressible waves (such as shock waves in supersonic flows), which frequently exceed acceptable levels in practical circumstances such as military and surveillance aircraft [41].

There are several studies that have reported on jet control, and we consider some cases in this review. It was observed that the high-speed flow controlled by the excitation of free shear-layer instabilities [42] uses localized arc filament plasma actuators in jets for different Mach numbers at a supersonic range. Focusing the aspect ratio of the nozzle and nozzle pressure ratio (NPR) with the Mach number variation, the elliptic jet control with limiting tab [43] was investigated and showed that each parameter is important to control the jet flows, similar to the overexpanded plug nozzle jet [44] controlled by the passive method. Additionally, some researchers used ventilated triangular tabs to control the jet [45], control the supersonic elliptic jet with ventilated tabs [46], and to measure the impact of the tab location relative to the nozzle exit on the shock structure of a supersonic jet [47].

Khan et al. [48] experimentally investigated the effect of the extended cowl on the flow field of planar plug nozzles for two different Mach number ranges (1.8 and 2.2) to observe the influence of the cowl length for the pressure distribution. Manigandan and Vijayaraja [49] experimentally investigated the flow-field and acoustic characteristics of the elliptical throat in the CD nozzle. According to the findings, switching from an elliptical to a circular throat alters the shock cell architecture, resulting in a substantial shift in the scream amplitude, owing to wave weakening. The jet controlled for mixing the flow was experimentally studied by Khan et al. [50] for the enhancement of the supersonic 
twin-jet mixing by vortex generator to observe the effects and the behavior of the daughter streams. Similarly, an impinging plug nozzle jet using a vortex generator [51] was studied experimentally. Figure 4 shows the nozzle and tab details, CAD drawing (Figure 4a), photographic view without tabs (Figure 4 b), schematic sketch of nozzle exits with triangular tabs along the major and minor axes (Figure 4c), and triangular tab dimensions and the photograph of the nozzle with triangular tabs along the major axis (Figure $4 \mathrm{~d}$ ).
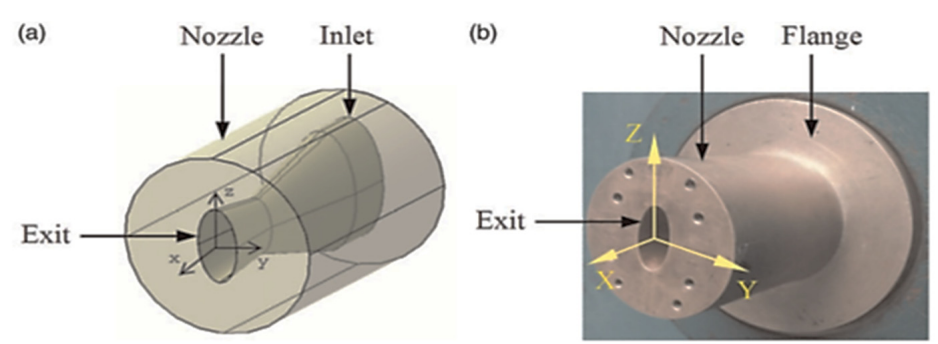

(c)
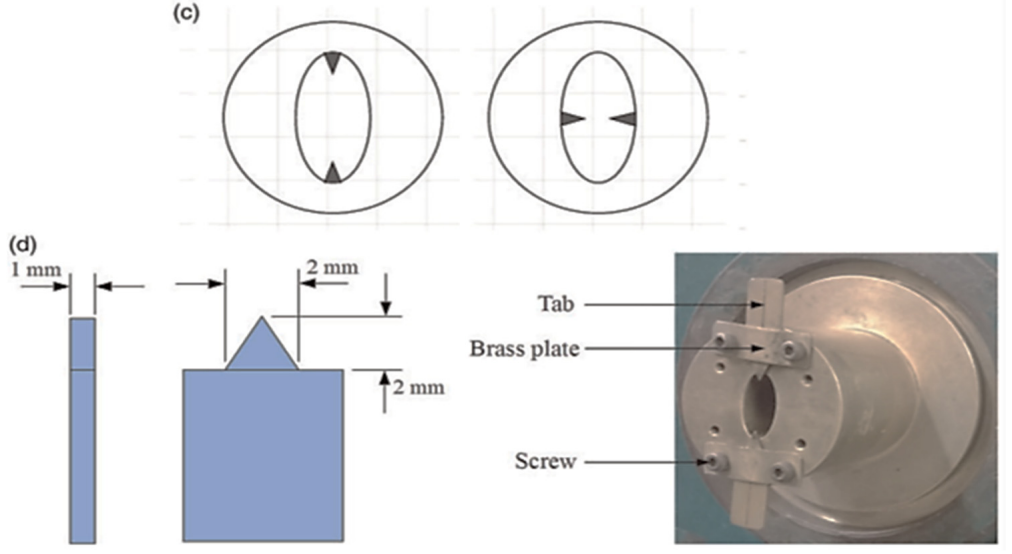

Figure 4. Jet control device, (a) Nozzle drawing, (b) Nozzle image without tabs, (c) Both minor and major tabs on the nozzle drawing (d) Triangular tabs dimension and nozzle image with major tabs [52].

\subsection{Noise Control}

In the past, the decrease in shock-related noise from aviation engines operating at supercritical nozzle pressure ratio received attention. The fact that shock-related noise occurs on many engines, including the turbofan engines utilized in today's commercial aircrafts, emphasizes its relevance. It has long been known and shown in model scale tests that employing a proper CD nozzle instead of a convergent nozzle, as used in most supersonic aircraft engines, may minimize/remove the shock noise component [53]. However, due to many unsolved issues concerning the noise characteristics of CD nozzles operating under non-design circumstances, the actual application of this idea has been avoided [54]. Although an appropriate CD nozzle may be used to produce a shock-free jet flow at a certain design pressure ratio, the same nozzle can be used for off-design pressure ratios during takeoff and landing operations, resulting in shock noise [55].

The bulk of these noise reduction systems are referred to be passive since they cannot be switched off or changed while in flight and might result in performance losses. Penn State [56] is developing a fluid insert technique for supersonic jet noise reduction. The fluid insert method aims to reduce noise in low bypass ratio turbofans while having minimal impact on engine performance. The fluid inserts blast air into the diverging portion of the nozzle on demand, which may be turned off or adjusted depending on the flight regime. Although significant research has been conducted in the form of noise measurements and Reynolds-averaged Navier-Stokes (RANS) calculations to enhance the fluid insert technology $[57,58]$, the reason why these inserts work is still not understood completely. The correlation of changes in the flow field with corresponding changes in the noise is inadequate, using only existing RANS data $[59,60]$. It was suggested that unstable scale- 
resolving simulations be used to obtain more insight into the flow field and to better understand noise reduction techniques [56]. Additionally, when properly structurally supported, acoustic reflectors of an adequate scale are a suitable noise reduction solution for the high-pressure venting typical of blowdown operations [61]. Due to disadvantages, such as delayed convergence and the complexity of the phase shift mechanism, a unique technique was used that does not use secondary path modeling [62] and the sensitivity of noise to system uncertainties [63]. Fluid inserts reduce the convection speed of wave packets in the jet shear layer, resulting in a reduced Mach wave radiation angle [64].

This interaction is discussed here with a focus on noise creation and reduction when a jet is parallel to or impinging on a solid wall. Various researchers have presented computational methods [65,66] with large-eddy simulations [67-71], high fidelity simulations [72] and 3D simulation [73]. The noise reduction of supersonic jets by nozzle trailing-edge changes was investigated experimentally [74], and hemispherical noise reduction reflectors on transonic jet flows [75] were conducted. Different injection sites, angles, and circumstances were also investigated, resulting in distinct acoustic behavior and flow-field changes [76]. Using steady fluidic injection, researchers conducted an empirical scaling analysis of supersonic jet control [77]. Aft and lateral wall inclinations for a cavity [78] supersonic cavity flow utilizing high-speed upstream injection [79] and cavity dynamics to the introduction of various storage configurations installed at different positions inside the cavity [80] were all numerically modeled for noise reduction. The employment of a single injector as a fluid insert helps break up the large-scale structures of the flow, according to direct cross-correlations of near-field data with far-field microphone signals [81]. Pipe-jet noise is reduced via geometric changes in the form of trailing edge castellations. The interaction between the streamwise vortices is determined by the number of castellations, which changes the sound generated [82]. Figure 5 shows the noise reduction configurations, which are adopted in the nozzle exit region, and represents the baseline nozzle (Figure 5a), nozzle (Figure 5b), schematic of a single fluid inserts in the nozzle (Figure 5c), and designation of different azimuthal planes for the 3FC-2FI nozzle (Figure 5d).

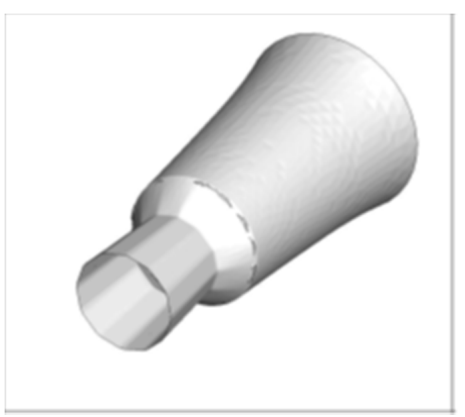

(a)

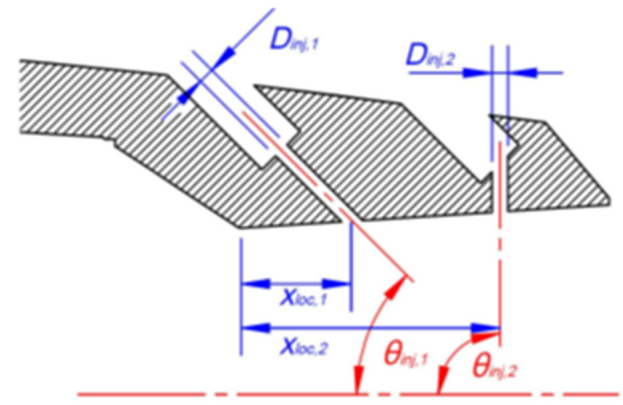

(c)

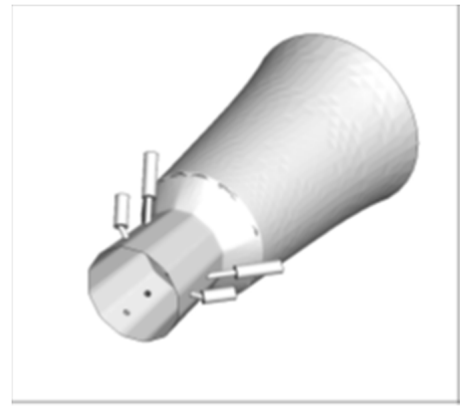

(b)

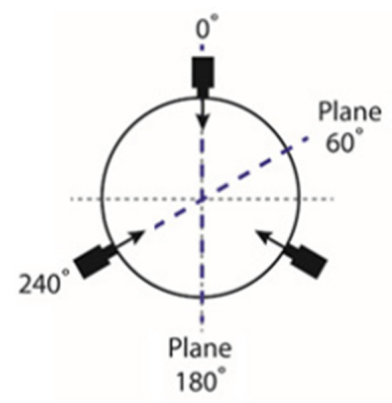

(d)

Figure 5. Details of nozzle configurations. Reprinted with permission from ref. [64]. Copyright 2020 Springer. 


\section{Active Control Methods}

The major consideration of this review work is to explore the active control methods of supersonic flows. Therefore, this section is split into the methodologies employed by the researchers: experimental, CFD, and soft computing approaches.

\subsection{Experimental Investigation}

The wall and base pressure in the suddenly extended duct were measured by changing the geometrical and flow parameters of the CD nozzle by Khan et al. [15]. The Mach number can vary in any supersonic range, as seen in Figure 6 (CD nozzle with a larger duct). To build a CD nozzle, the exit diameter of the nozzle may be kept constant, as the base pressure results for nozzles with an exit diameter are accessible in the literature [15]. To calculate the throat diameter, the isentropic relations were utilized [5]. The nozzles are calibrated after manufacture in order to determine the exact Mach number at the nozzle exit.
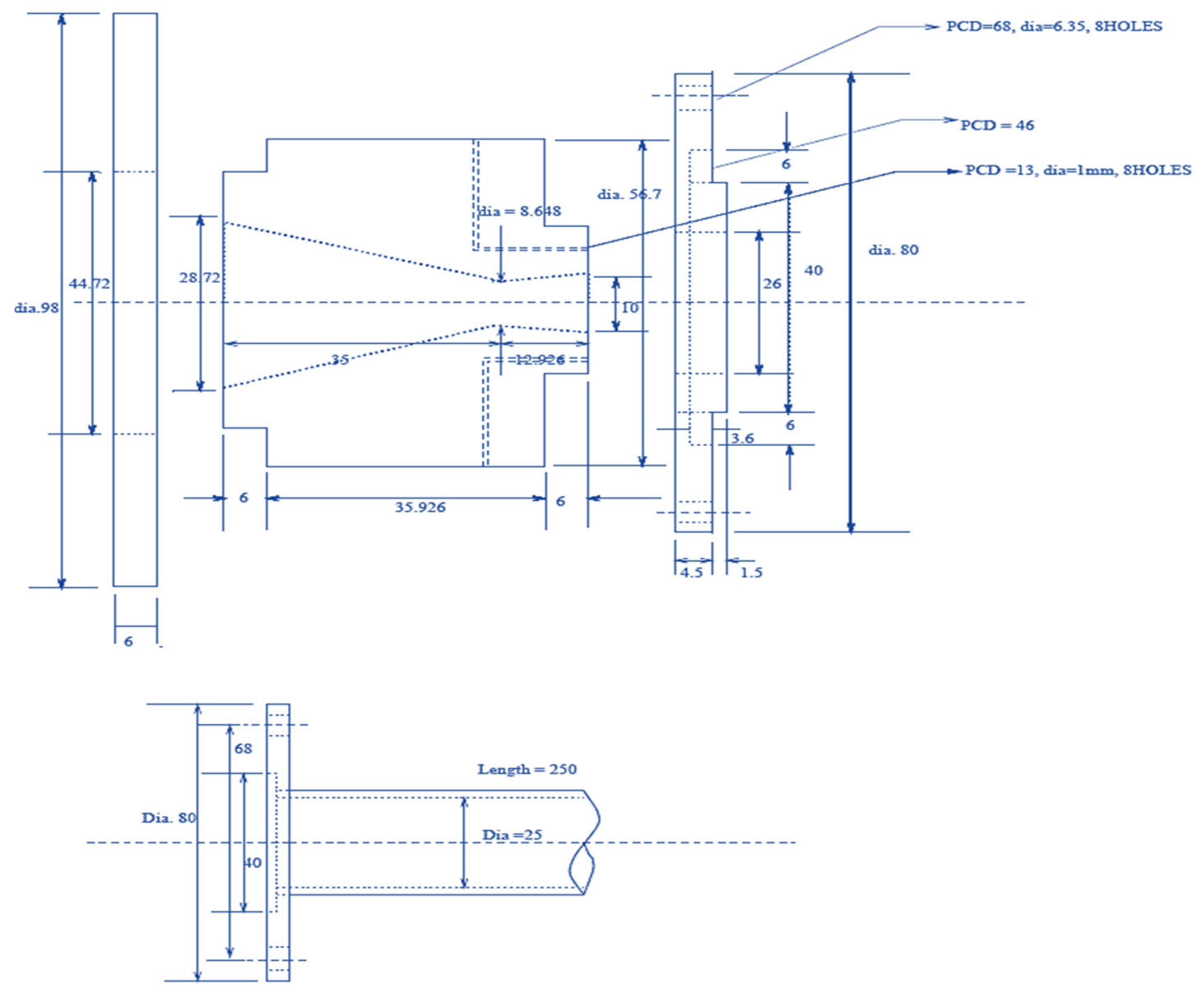

Figure 6. Flow expansion, nozzle, and enlarged duct design for Mach number 1.87.

The experimental test model was an axisymmetric CD nozzle that was attached to a concentric axisymmetric tube with an area ratio, and it could be adjusted. Figure 7 depicts a perspective of the experimental setup that was used for experimentations. The researchers used a pitch circle diameter of $13 \mathrm{~mm}$; there were eight micro-holes, four of which (designated as c) were used for blowing, and the other four (labeled as $\mathrm{m}$ ) were used to record the base pressure. Controlling the base pressure was accomplished by blowing through control holes (c) with air from the primary settling chamber [15]. The pressure taps are shown in Figure 7 together with the rapid expansion duct. A perspective of the experimental apparatus is shown in Figure 8. Brass was utilized for the investigations dramatically enlarged ductwork. Lower L/Ds were then achieved by machining the duct 
after measurements for a certain length of pipe were completed. Pressure taps made of stainless steel were used to record the static wall pressure. Because the flow field soon after departing the nozzle is so important, the first nine holes were spaced four millimeters apart, and the remaining holes were spaced eight millimeters apart. The moisture content of the compressed air is absorbed in a dual-tower semi-automatic silica gel dryer. Later the dried air is heated and used to remove the moisture from the air altogether. A regulatory pressure valve operated by a pressure relief pilot permits the dryer to operate; three tanks were used to store the dry air with a total capacity [1].

In previous experimental methods, the NPR was 3 to 11 at various expansion levels and showed that the L/D could be defined for a given Mach number and NPR, resulting in a cumulative increase/decrease in the base pressure [1,83-88]. The experiments were also conducted by [89] for area ratio 2.56 and area ratio 4.84 [90]. The statistical approach aims to verify the experimental data, obtained at the VTI Žarkovo Institute during supersonic wind tunnel tests: free escape and flow with one chosen type of obstacle [91]. The tests were carried out at design NPR with sudden expansion for the duct length $L=10 \mathrm{D}$ to $1 \mathrm{D}$. The considered cross-sectional areas of the tube were 2.56, 3.24, 4.84, and 6.25 [92]. Figure 7 shows the experimental setup for the base and wall pressures.
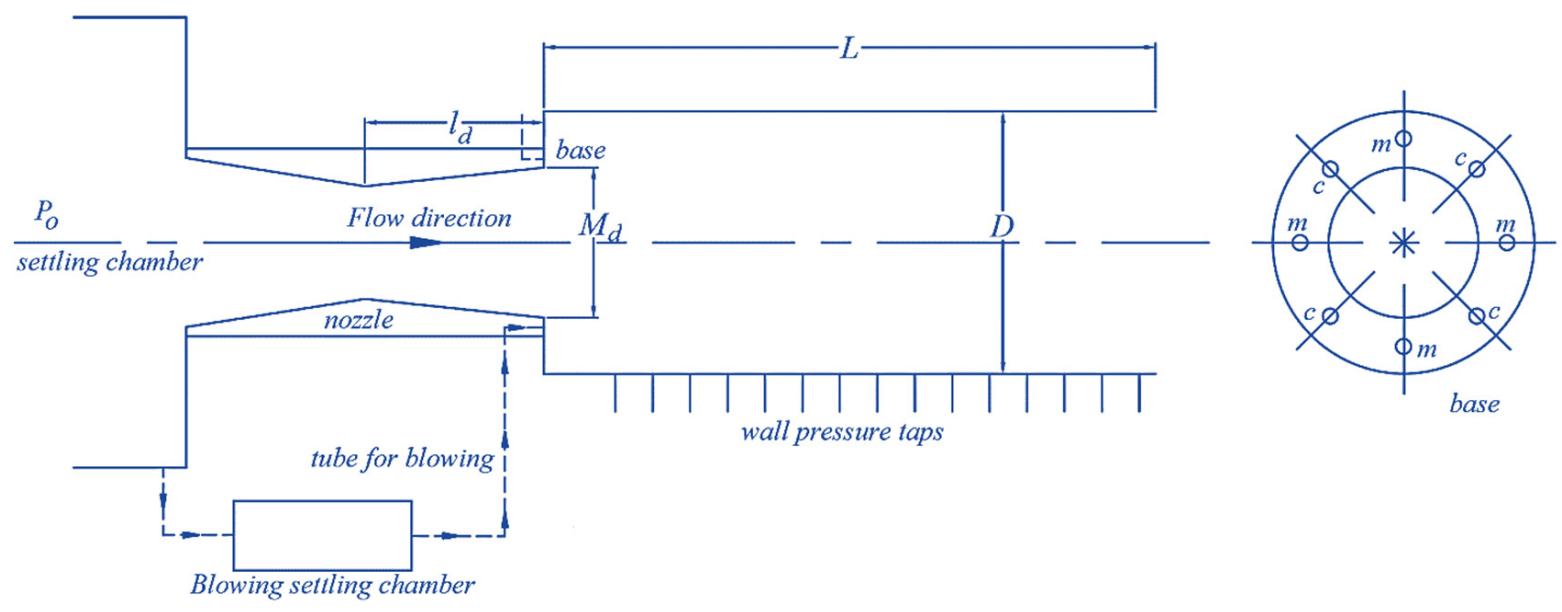

Figure 7. Experimental setup [93]. Reprinted under the Creative Commons (CC) License (CC BY 4.0).

In the presence and absence of a base cavity, the experiments were conducted to analyze the pressure variations in the base region of a conventional missile configuration at a freestream Mach number of 0.7. The authors attempted to identify the variations in pressure and illustrate the influence base cavities have on their behavior. Experiments consisted of unstable calculations of pressure at six azimuthal locations. The disparity in the pressure fluctuations in the azimuthal direction was observed due to a standard axisymmetric, which is significant [35]. For the Mach numbers ranging from 1 to 3 , the effect of the microjet control in the CD nozzle with a sudden expansion duct was experimentally tested at supersonic Mach numbers. The research varied nozzle parameters, such as an area ratio of 2.56; NPR ranged from 3 to 11; and L/D ranged from 10 to 1 [94]. They extended their work for Mach 2.5 and 3.0, and cross-sectional areas of 2.56, 3.24, 4.84, and 6.25; the $\mathrm{L} / \mathrm{D}$ ratio of the duct was 10 to 1 , and the NPR used were from 3 and 11 [95].

To control the drag, the researchers [96] worked with base drag and experimentally studied the aerospikes behind the base of bluff bodies. A $1 \mathrm{~mm}$ thick plate with two spikes at $11.5 \mathrm{~mm}$ was mounted between the nozzle as a passive device. The efficacy of the continuous grooved cavity was tested experimentally to control the base flows with specific parameters [97]; in the transonic system, the aerospikes effectively control the base pressure [98] without disrupting the main flow, respectively. 


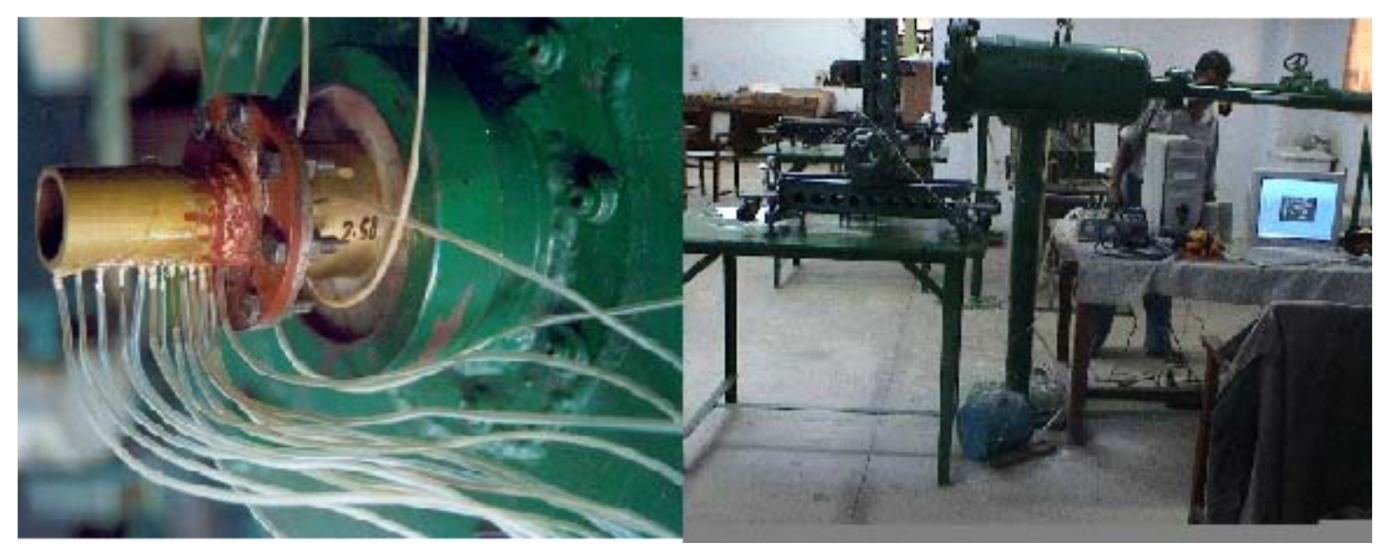

Figure 8. A view of the extended duct with pressure tapings and setup site [97]. Reprinted under the Creative Commons (CC) License (CC BY 3.0).

In summary, Khan et al., investigated the active control of the base pressure [1,15,82-85,99] in which they considered the differed Mach number at various supersonic flow ranges, such as Mach numbers 1.25, 1.30, 1.48, 1.6, 1.8 and 2.0 in [84,85]; 1.87, 2.2 and 2.58 in [15]; and 2.0, 2.5 and 3.0 in [82], respectively. The test area ratio was from 2.56, 3.24, 4.84, and 6.25; the NPR was from 3 to 9; and the duct length for $\mathrm{L}=10 \mathrm{D}$ until 1D. More attention was given in the recent study to wall pressure distribution for different inertia levels, relief to the flow, NPR, and the L/D ratio [93,100-107]. After monitoring the flow from the active microjet control, it is also necessary to know whether the flow changes in the duct or not. Hence, recent findings have also shown that several studies are conducted with equivalent or variable Mach number and area ratios with the same NPR and L/D ratios. The majority of wall pressure flows were considered with varying the area ratio, such as $2.56[93,100]$, $3.24[101,102,108,109], 4.84[103-105,110]$, and varying the Mach number for the same area ratio 2.56 with Mach 2 and 3 [106], 1.3. 1.9, and 2.4 [111] and for the area ratio 6.25 with Mach 1.1 and 1.5 [112] and 2.1 and 2.8 [113].

\subsection{Computational Fluid Dynamics Approach}

As the second method of this study on high-speed flow control, a CFD approach was chosen, and a relative work is overviewed to examine the objective and outcomes of the previous investigation.

Apart from experimental studies, a numerical method was employed by various researchers; such studies can be seen in this section. A fluid-structure analysis was found for the delta wing (cropped) [114] based on an aeroelastic solver in the time domain. Two fluidic thrust modulation methods were employed—shock thrust and throat shifting thrust modulation [115] — for the investigation. Initially, the CFD approach examines the supersonic flow through a de Laval nozzle and obtains complete isolation of the thrust flow due to shock waves. The flow was studied for friction, and the temperature of gases at the exit of the combustion chamber [116]. The finite volume model was developed for the estimated two-dimensional and three-dimensional flow formations, using turbulence model efficacies via ANSYS simulation [117]; it was used to investigate the extensive flow field within the supersonic ejector and improved the ejectors mixing chamber wall structure to attain an optimum entrainment ratio to obtain the highest possible capability the ejector can achieve. The ANSYS fluent and ICEM meshing tool was used to conduct the simulation and analyze the ejector performance: k-epsilon realizable and k- $\omega$ SST [118] and k- $\omega$ [119]. To find the micro-Laval nozzle performance, it was primarily investigated by its machined surface topology, and a circular cross-section micro-Laval nozzle was modeled [120].

Modeling of the nozzle geometry and generating mesh was carried out using the GAMBIT 2.4 program and validated with the findings of the experiment taken from the literature, which are well known [121]. Patel et al. [122] derived the principles of 
the de Laval nozzle, using the nozzle operating theory, and examined the experimental approach of evaluating flow for various nozzles; the variance of flow parameters, such as pressure, temperature, velocity, and density, was visualized [123] to investigate the effects of geometry and flow parameters on the thrust force created by the flow from the CD nozzles to a circular duct with a larger cross-section. The study was carried out for all Mach numbers using various area ratios (2-12) and NPR (3 to 11) [124-127]. The researchers optimized the rocket air ejector configuration in AutoCAD, then analyzed it using Ansys CFX using the numerical approach with 3D models [128]. The primary purpose was to optimize the CD nozzle location for each operating circumstance and the influence of reflected shock waves and boundary layers on the ejector performance in the mixing chamber constant zone [129]. To compute the mass flow rate and multiphase sound velocity for a CD nozzle, the equilibrium and homogeneous model that gives rise to no-slip in temperature and velocity between the particle and gas phases was used [130]. Additionally, the mixing noise and shock-related wideband noise [131] in a nozzle was discussed. The CFD methodology was also employed in this definition for varied area ratios, the Mach number, NPR, and L/D, and analyzed the flow region surrounding the base [132].

Meanwhile, it was found that ANSYS fluent was the most appropriate tool to solve this problem. The CFD approach was a dominant concept in ANSYS software and a foundational analysis to settle the problem. It is essential to know the governing equations and the turbulent modeling of the current flow. In this respect, the studies examined and illustrated the testing approach and identified an issue for situations considering the various nozzle parameters and the flow range. In the analysis, the L/D of 10 was used for the conduit. An area ratio between the exit area of the CD nozzle and the duct area was also found and observed in the flow formations (Figure 9). The idea is used by the CFD method for various area ratios, the inertia level, NPR, and the duct length [14,132-137] for the compressible flow.

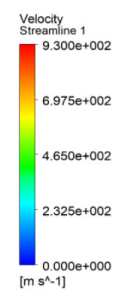

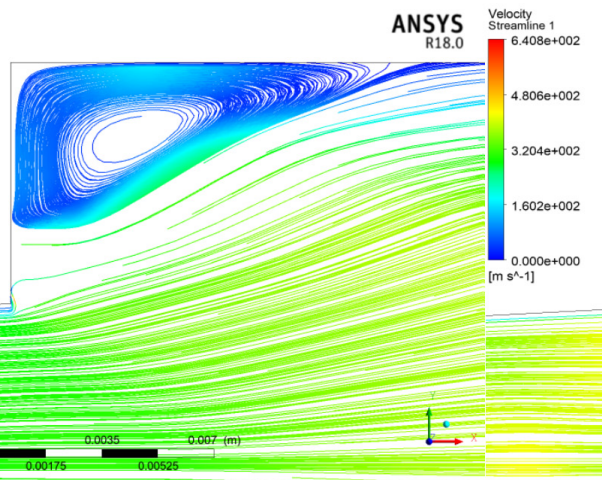

(a)

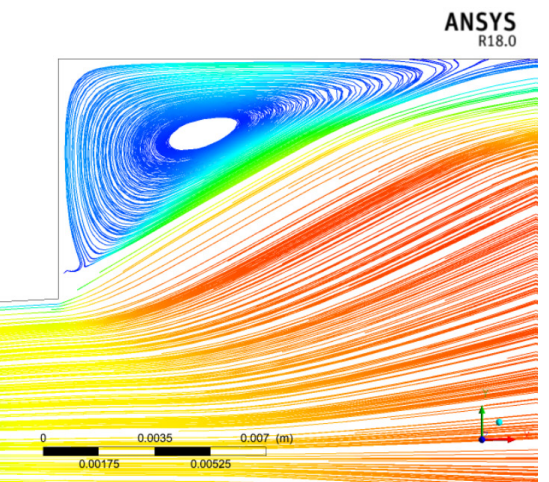

(b)

Figure 9. Velocity streamline for area ratio 6.25 (a) with control (b) without control [132]. Reprinted under the Creative Commons (CC) License (CC BY 4.0).

The CFD procedure also used to explore the flow through the wedge [138,139], noncircular cylinder [137,140], splitter plate [141-143], airfoil [144,145] and powered submarine [146] for an incompressible flow range. From the fluent, more studies were found in recent years in which some studies have been utilized with the pressure-based solver, and K-epsilon turbulent modeling was used $[134,136]$. The fluent results were continued with a change in parameters to investigate the effect of active microjet controller [2,147]. Figure 10 shows the perfect $2 \mathrm{D}$ model with the contour received as a result. 


\subsection{Soft Computing Methods}

Soft computing is an emerging technology for discovering these kinds of problems, which parallel the remarkable capacity of the human imagination to target and study in an atmosphere of ambiguity and imprecision. It contains many computer models, including experimental system architecture, fuzzy set theory, neural networks, and approximate reasoning, and it requires intensive computing for learning and reworking.
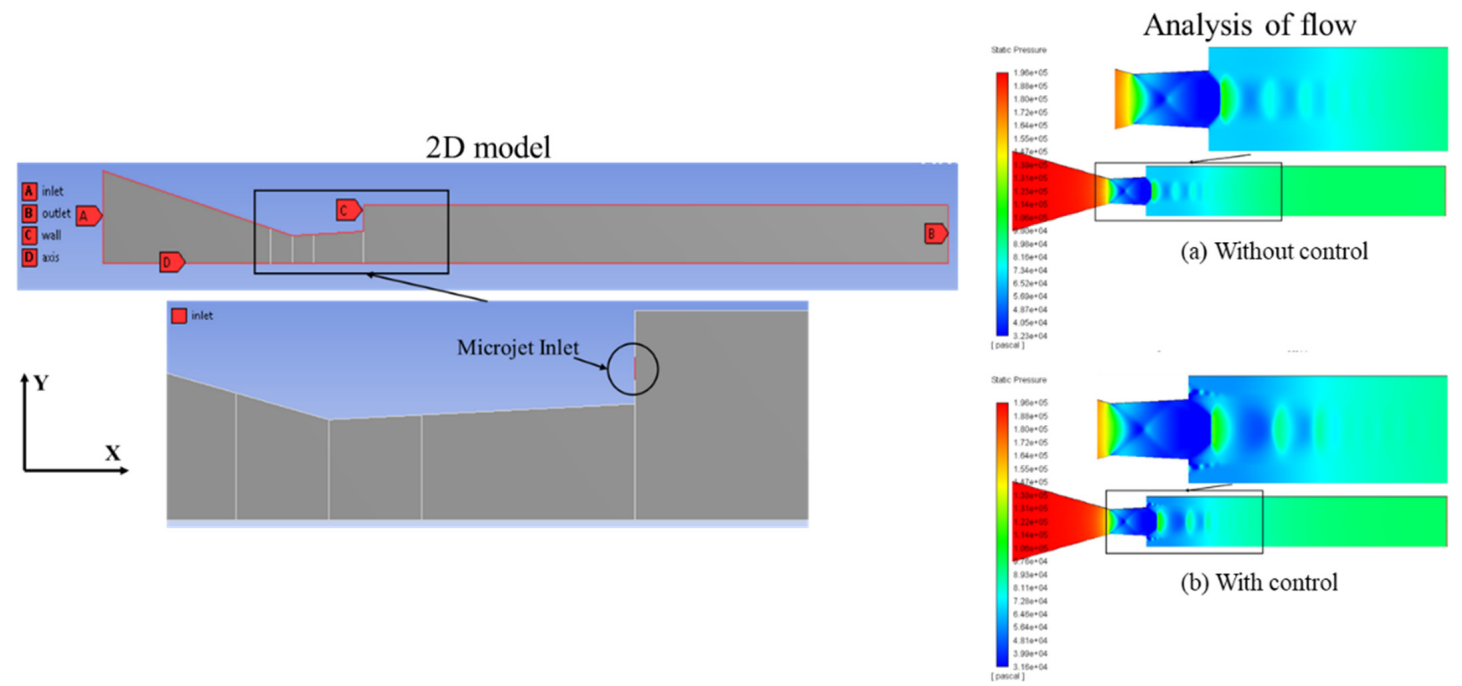

Figure 10. D nozzle with sudden expansion duct and their results. Reprinted with permission from ref. [2]. Copyright 2021 Springer.

\subsubsection{Design of Experiments}

If one needs to verify scientific predictions properly, these measurements are valuable. In several engineering and medicine implementations, the design of experiments (DOE) method was used to define the variables that are important in the production and optimization phase to accomplish a helpful target. This approach was then used to find the most prevalent strategy for the solution of the current object. The DOE plays a vital role in identifying relevant variables in the development process for industrial uses, such as planning and experimentation [148-150]. These kinds of elements were used successfully with the influence of designer control and changes over two or three stages. The experiments were carried out based on the orthogonal array (OA) to obtain each possible response factor affecting the input variables.

Researchers used the DOE principle based on the current problem and found that this could be an efficient way to achieve the base pressure control with an appropriate parameter. Therefore, to refine the base pressure control, the DOE technique was used. The impact of microjets on control was achieved to obtain base pressure differences of various parameters. The general DOE approach method can be seen in Figure 11.

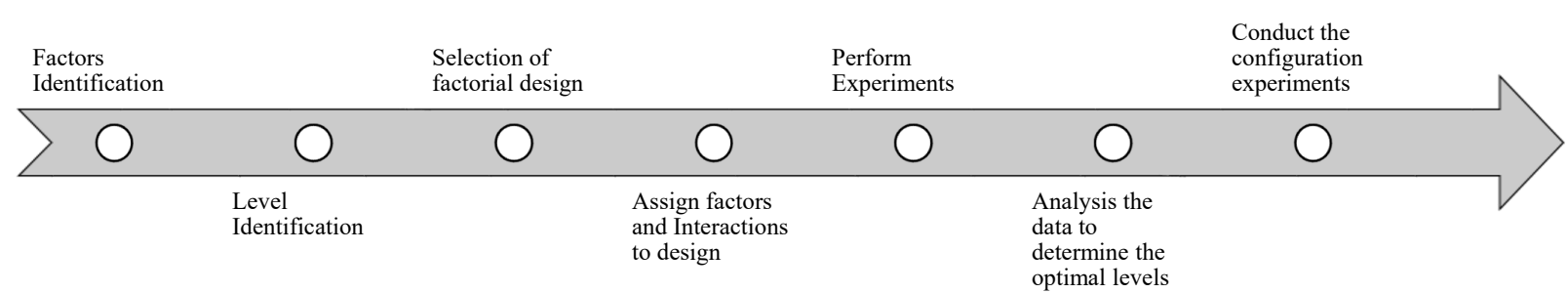

Figure 11. Steps in implementation of DOE approach. Reprinted with permission from ref. [2]. Copyright 2021 Springer. 
The experimental study was used for various parametric combinations using microjets to control the base pressure, using a CD nozzle. The data were used to refine the optimal mix of parameters employed to provide precise control of base pressure for improved performance with DOE [151]. A Taguchi design L9-OA and variance analysis (ANOVA) was used to analyze the influence of nozzle parameters affecting the base pressure. Multiple linear regression models, confirmation checks, and linear regression equations were performed for accuracy in an optimization. The ANOVA method was also used to obtain the individual parameters statistical significance on the total base pressure variability [152]. The observation on the control becomes effective for lower area ratio, compared to the higher area ratio with the aid of 15 arbitrary test cases; two linear regression model presentations were tested for their estimated accuracy [153]. To optimize the response surface methodology (RSM) of experimental data, non-linear regression models based on the central composite design (CCD) and box-Behnken design (BBD) were developed to simplify the input-output relationships [154]. The DOE with $\mathrm{L}_{27}-\mathrm{OA}$ and ANOVA was used to determine the feedback (in percentage terms) of various process parameters and their correlations with and without control on the base pressure $[155,156]$. The optimum nozzle parameters were targeted, such as convergent angle, divergent angle, and the throat radius of the nozzle; the best values were assessed based on the flow parameters [157]. Jaimon et al. [158] used the DOE method to predict the suddenly expanded flow with and without microjets as an active control. To develop the linear model, they used a complete factorial design of the $\mathrm{L}_{16}$ orthogonal array (OA). Using Taguchi's $\mathrm{L}_{27}$ orthogonal array, a regression analysis was made [159], and optimized results investigated the suitable parameters for base pressure control.

\subsubsection{Fuzzy Logic}

Jagannath et al. [160] discovered a fuzzy logic methodology for investigating pressure loss in a sudden expansion duct. The authors aimed to notice minor pressure loss when the L/D was 1, as evidenced by the fuzzy logic formulation. According to the authors, this can be a qualitative examination of internal fluid flow through a nozzle with a sudden expansion duct using the fuzzy logic methodology [161]. Because of all other characteristics, such as wall static pressure and loss pressure, including the base pressure, they discovered the best value of L/D. When the Mach number is changed to 1.58 or 2.06, all other parameters remain the same as in the sudden expansion duct with cavities [162]. They found that the fuzzy logic technique L/D of 1 is sufficient for smooth flow growth based on de Laval nozzle and wall static pressure changes in both circumstances. Quadros et al. [163] described the critical aspects of the fuzzy logic technique in turbulent supersonic flow simulations as a cost-effective methodology. The Mamdani-based fuzzy logic methodology was utilized to build connections between input and output in the CFD findings. Triangular, generalized bell shape and Gaussian membership functions were employed in this technique.

\subsubsection{Machine Learning}

A neural network was employed to examine the predicted floor pressure in a convergent nozzle with shallow cavity internal flows at various subsonic Mach numbers [164]. The authors used feedforward neural networks (NNs) to highlight the modeling problem. A mixed density network was trained using an artificial neural network (ANN) methodology using the updated database of the future flow profile. The ANN [165] was used to learn and train flow characteristics over a transport aircraft configuration to estimate the aerodynamic coefficients using different network sizes. The K-means technique was used to cluster this massive amount of data. According to the RSM, microjets are efficient when a favorable pressure gradient influences the flow. The effect of a lower area ratio and a longer duct length on the base pressure is minimal. Furthermore, the random forest strategy was applied, which belongs to this group and is employed in Bootstrap aggregation employment regression and classification research [166]. Heat maps are used to visualize the massive amount of experimental data generated. Six back-propagation neural network 
models (BPMs) based on input and output possibilities are built to forecast pressure in high-speed flows for the first time. The six BPMs with two hidden layers containing four neurons were determined to be the best suited for regression analysis. The very non-linear values of the base and wall pressure are correctly predicted by BPM 5 and BPM 6 [167]. Figure 12 depicts a broad schematic depiction of the back-propagation model (BPM).

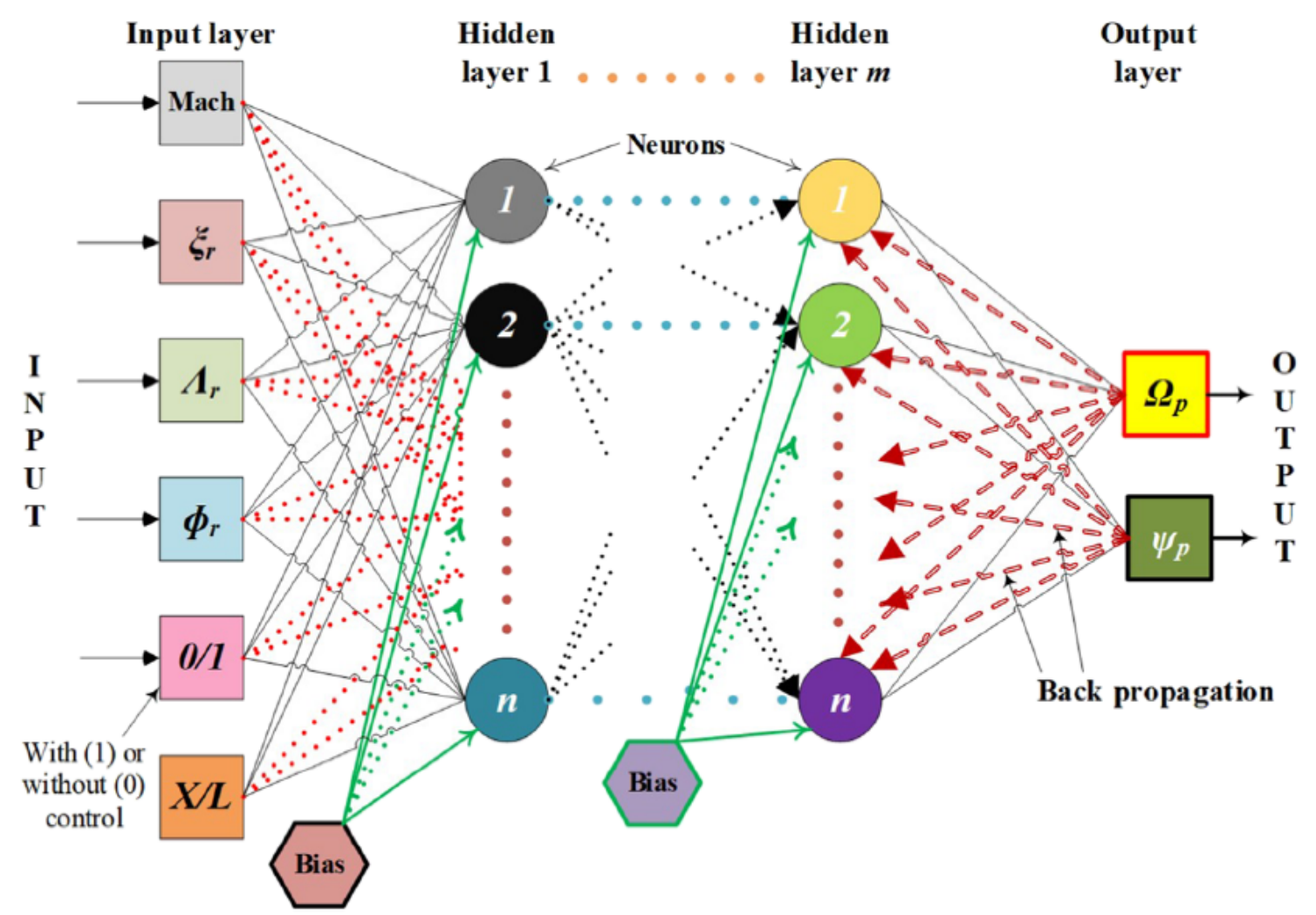

Figure 12. Back-propagation for base pressure modeling. Reprinted with permission from ref. [167]. Copyright 2020 AIP.

\section{Critical Analysis of Literature}

After conducting an exhaustive review on active flow management by blowing compressed air at the duct base, it was observed that the researchers utilized experimental, CFD and soft computing methods for determining the flow formation inside the nozzle (Figure 13). The experimental method was used in maximum cases for which it was challenging to obtain high-speed flow formations inside the duct, with shadowgraph for clear demonstration. Hence, the researchers utilized the CFD methods; it is easier to obtain the contours for the different variations of the flow parameters. Multiple high-speed supersonic flows were studied well by the researchers. In the CFD, different turbulence models were used to investigate the effectiveness of the aerodynamic flow variations; the limitation found was that there is a lack of three-dimensional modeling and analysis, which can be explored well in future investigation.

Next, a soft computing approach was recently found to optimize the parameters on pressure flows; several studies have been reported via DOE. However, in few cases, machine learning and fuzzy logic methods stated that the optimum results can predict from the standard statical methods. A valuable combination of parameters in the development and optimization of the flow process examines the necessary factors to achieve. Therefore, soft computing minimizes the number of experimental and theoretical workflows for a given situation. That can be more on future work for the researchers to measure the microjet effect on the nozzle pressure control and to find the optimum parameters for controlling 
the base pressure. However, there are no studies have been reported in the literature on either theoretical or analytical approaches with fundamental governing equations.

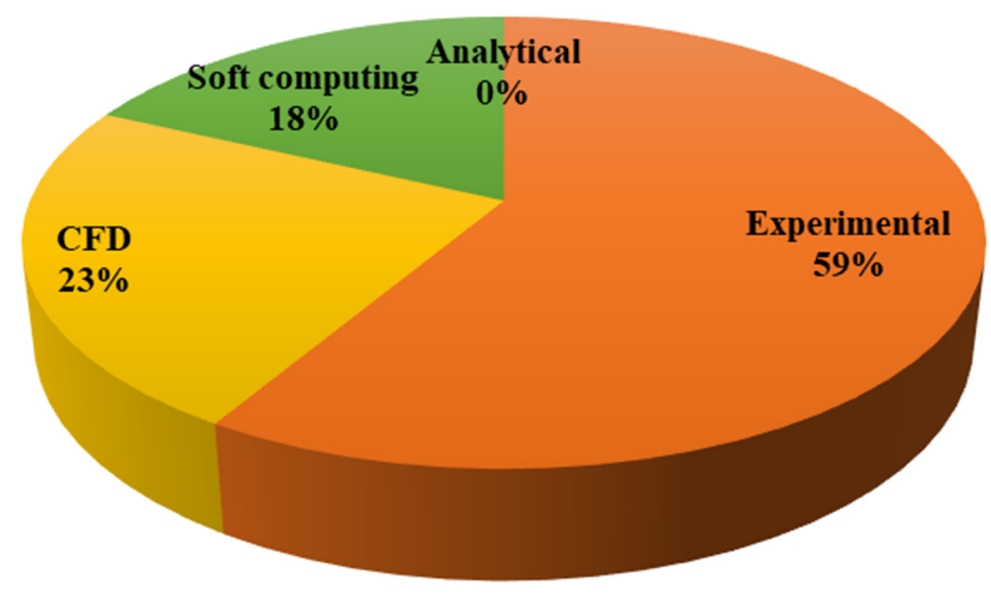

Figure 13. Methodologies used for active flow control.

In contrast, some of the passive control devices are shown in this review to know another type of control method of high-speed flow, jet, and noise. One of the critical issues in passive control is the need for additional energy sources to activate the control mechanism. Indeed, the present literature focuses more on active control and their scenarios. Some of the significant gaps/observations between the methodology related to the present work are shown in Table 1.

Table 1. Major observation for active flow control.

\begin{tabular}{cccccc}
\hline S. No. & Control & Experimental & CFD & Optimization & Remark \\
\hline 1 & Active & $\checkmark$ & $\checkmark$ & $\checkmark$ & $\begin{array}{c}\text { Very recently, CFD and } \\
\text { optimization studies were } \\
\text { found, and still a lot of scope } \\
\text { in optimization }\end{array}$ \\
\hline 2 & Passive & $\checkmark$ & $\checkmark$ & $\checkmark$ & $\begin{array}{c}\text { Several studies have been } \\
\text { reported in all approaches }\end{array}$ \\
\hline 3 & $\begin{array}{l}\text { Without } \\
\text { Control }\end{array}$ & $\checkmark$ & $\checkmark$ & $\checkmark$ & $\begin{array}{c}\text { Several studies have been } \\
\text { reported in all approaches }\end{array}$ \\
\hline
\end{tabular}

For in-depth analysis of methodologies adopted for the active control method shown by the trends plot, we consider the past two decades. From the graphical view, it has clearly shown that many works have been done with the experimental method in the early years as discussed previously. However, due to recent advanced technologies, such as simulation and data optimization tools, experimental work was reduced in recent years and the soft computing approaches have increased, which have found advantages in research work. Indeed, until now, no mathematical model was made to predict the exact pressure values before and after the microjet controller. The researchers utilized different techniques to predict the results in a flow object. This gives an idea of how the methodologies are increasing in the current scenarios as a scientific approach to solving the respective problem, such as flow control. Figure 14 illustrates the last 20 years of work related to the current study in percentages, considering different techniques used to evaluate the pressure values.

In another consideration, trends in the control of flow are considered a flow model, such as nozzle/jets, bluff body, and airfoil (Figure 15). Nozzle/jets are a type of highspeed configuration that was found in several studies from the past two decades for aerospace applications. Next, the bluff body is also considered to know flow formation, and it is controlled with passive devices, such as splitter plates, for the application of both 
automotive and aerospace industries. Lastly, airfoil is found in many studies but in most of the cases, this has been only developed to investigate the aerodynamic forces in some studies where the outer flow control was found.

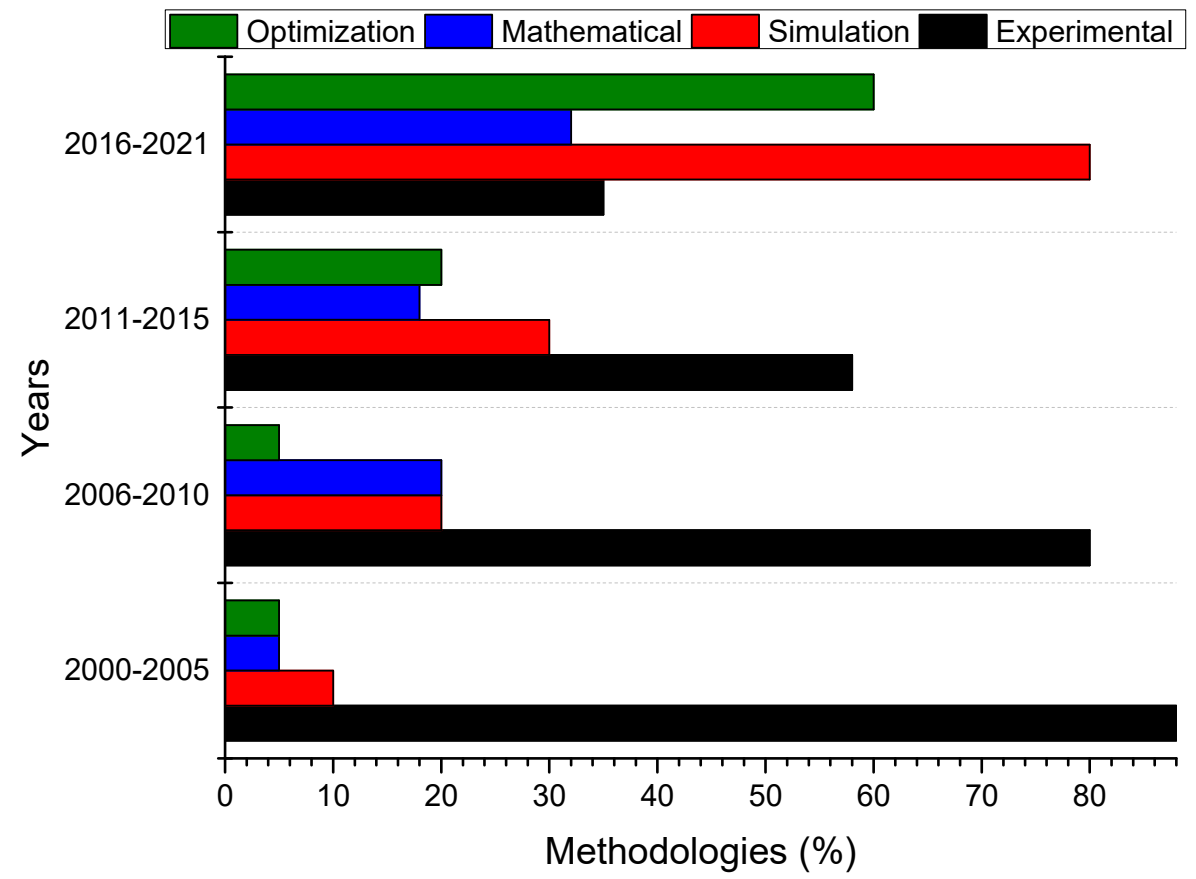

Figure 14. Trends in research methodologies in active control of flow.

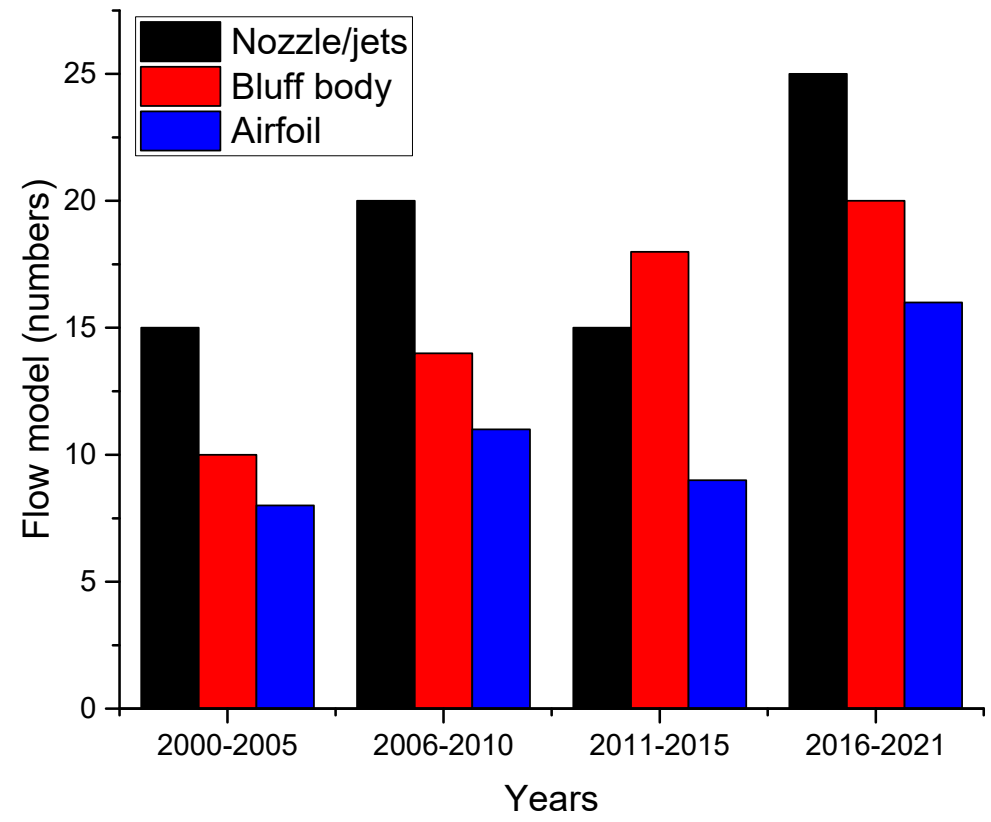

Figure 15. Trend's inflow model and its control.

Apart from the microjet controller for the control of high-speed flow, the researcher utilized different objects, such as smart material (actuator) to control the high-speed flow when focused on the depth of the active control approach. In addition, the devices for the flow control were found in the form of the cavity, corner model, diffuser, bluff body, cylinders, airfoil, wedge, etc. In all studies, some outer flow controlled, and some inner flow controlled was investigated. Table 2 illustrate the summary of the previous work with the limitations in their studies. 
Table 2. Summary and limitations of the flow control method.

\begin{tabular}{|c|c|c|c|c|}
\hline Type of Object & Technique Adopted & Focused Parameter & Limitations & Reference \\
\hline $\begin{array}{l}\text { Compression corner } \\
\text { calculation model }\end{array}$ & $\begin{array}{l}\text { ANSYS Fluent with } \\
\mathrm{k}-\varepsilon \text { turbulence model }\end{array}$ & $\begin{array}{l}\text { Numerical investigations in the } \\
\text { supersonic flow field with } \\
\text { different injection pressure } \\
\text { ratios, actuation positions, and } \\
\text { nozzle types }\end{array}$ & $\begin{array}{c}\text { The only simulation was used for } \\
\text { investigation }\end{array}$ & {$[36]$} \\
\hline $\begin{array}{l}\text { CD nozzle with } \\
\text { sudden } \\
\text { expansion duct }\end{array}$ & $\begin{array}{l}\text { Experimental, CFD } \\
\text { and DOE }\end{array}$ & $\begin{array}{l}\text { Effect of microjet control in a } \\
\text { sudden expansion duct with the } \\
\text { parametric investigation }\end{array}$ & $\begin{array}{l}\text { Numerical investigation done by } \\
\text { 2D model and microjet location is } \\
\text { fixed to a single point }\end{array}$ & {$[2]$} \\
\hline $\begin{array}{l}\text { CD nozzle with } \\
\text { sudden } \\
\text { expansion duct }\end{array}$ & $\begin{array}{l}\mathrm{RSM} \text {, clustering, and } \\
\text { random forest } \\
\text { regression }\end{array}$ & $\begin{array}{l}\text { Pressure in suddenly expanded } \\
\text { high-speed aerodynamic flow }\end{array}$ & $\begin{array}{l}\text { Predicting the pressure values } \\
\text { using the optimization method } \\
\text { with and without microjet } \\
\text { controller }\end{array}$ & {$[166]$} \\
\hline $\begin{array}{l}\text { Resonant high-speed } \\
\text { cavity }\end{array}$ & $\begin{array}{l}\text { Wind tunnel test with } \\
\text { a blowdown-type } \\
\text { facility }\end{array}$ & $\begin{array}{l}\text { High-frequency pulsed } \\
\text { supersonic microjets to control } \\
\text { resonant high-speed cavity flows }\end{array}$ & $\begin{array}{c}\text { The fact that the REM/ SmartREM } \\
\text { actuator performance can be } \\
\text { enhanced }\end{array}$ & [35] \\
\hline $\begin{array}{l}\text { Cylindrical cavity } \\
\text { structure takes }\end{array}$ & $\begin{array}{c}\text { A computational } \\
\text { method based on } \\
\text { high-order numerical } \\
\text { techniques }\end{array}$ & $\begin{array}{l}\text { Flow physics of a pulsed } \\
\text { microjet actuator for high-speed } \\
\text { flow control }\end{array}$ & $\begin{array}{c}\text { Efficient and geometrically } \\
\text { complicated pulsed actuators were } \\
\text { developed for various high-speed } \\
\text { flow and noise control }\end{array}$ & [168] \\
\hline $\begin{array}{l}\text { Ultra-compact } \\
\text { serpentine inlet }\end{array}$ & $\begin{array}{l}\text { Experimental work } \\
\text { with high-pressure air } \\
\text { supply and CFD }\end{array}$ & $\begin{array}{l}\text { Microjet flow control in an } \\
\text { ultra-compact serpentine inlet }\end{array}$ & $\begin{array}{l}\text { Mach number of inlet throat } \\
\text { between } 0.2 \text { to } 0.5 \text {, and it is varied } \\
\text { to a higher number }\end{array}$ & [169] \\
\hline Crewless Arial Vehicle & $\begin{array}{l}\text { Experimental wind } \\
\text { tunnel test }\end{array}$ & $\begin{array}{l}\text { Microjet-based active flow } \\
\text { control on a fixed-wing UAV }\end{array}$ & $\begin{array}{l}\text { Experimental results possible to } \\
\text { simulate with the CFD model }\end{array}$ & {$[170]$} \\
\hline Impinging Jet & $\begin{array}{l}\text { Experimental work } \\
\text { with supersonic jet } \\
\text { facility }\end{array}$ & $\begin{array}{l}\text { Control of impinging supersonic } \\
\text { jet flows using microjets }\end{array}$ & $\begin{array}{l}\text { A fluent model will be helpful in } \\
\text { such an example }\end{array}$ & {$[171]$} \\
\hline $\begin{array}{l}\text { Supersonic } \\
\text { Crossflow model }\end{array}$ & $\begin{array}{l}\text { Experimental work in } \\
\text { a supersonic wind } \\
\text { tunnel }\end{array}$ & $\begin{array}{c}\text { Properties of } \\
\text { resonance-enhanced microjets in } \\
\text { supersonic crossflow }\end{array}$ & $\begin{array}{c}\text { Limited to experimental work and } \\
\text { also the Mach number can be } \\
\text { varied }\end{array}$ & {$[172]$} \\
\hline $\begin{array}{l}\text { Ahmed body and } \\
\text { NACA } 0015 \text { airfoil }\end{array}$ & $\begin{array}{l}\text { An experimental } \\
\text { study was conducted } \\
\text { in a subsonic wind } \\
\text { tunnel }\end{array}$ & $\begin{array}{l}\text { Active flow control by } \\
\text { micro-blowing and effects on } \\
\text { aerodynamic performances }\end{array}$ & Experimental work only & {$[173]$} \\
\hline Flap's pressure-side & $\begin{array}{l}\text { Experimental } \\
\text { approach }\end{array}$ & $\begin{array}{l}\text { Microjet configuration } \\
\text { sensitivities for active flow } \\
\text { control on multi-element } \\
\text { high-lift systems }\end{array}$ & $\begin{array}{l}\text { CFD and data optimization are } \\
\text { helpful techniques to predict the } \\
\text { multi-element high-lift system }\end{array}$ & [174] \\
\hline Flap's pressure-side & $\begin{array}{l}\text { Experimental } \\
\text { approach }\end{array}$ & $\begin{array}{l}\text { Surface-normal active flow } \\
\text { control for lift enhancement and } \\
\text { separation mitigation for } \\
\text { high-lift standard } \\
\text { research model }\end{array}$ & Other aerodynamic forces & {$[175]$} \\
\hline $\begin{array}{c}\text { Spaced jet } \\
\text { configurations }\end{array}$ & $\begin{array}{l}\text { Experimental } \\
\text { investigation }\end{array}$ & $\begin{array}{c}\text { Control of } \\
\text { compression-ramp-induced } \\
\text { interaction with } \\
\text { steady microjets. }\end{array}$ & $\begin{array}{c}\text { It is advantageous to utilize a } \\
\text { control design (MJ6) that functions } \\
\text { well }\end{array}$ & {$[176]$} \\
\hline Double-offset diffuser & $\begin{array}{l}\text { Experimental } \\
\text { technique }\end{array}$ & $\begin{array}{l}\text { Flow dynamics affected by } \\
\text { active flow control in an } \\
\text { offset diffuser }\end{array}$ & $\begin{array}{l}\text { Parametric study to predict more } \\
\text { accurate results from the } \\
\text { experimental data }\end{array}$ & {$[177]$} \\
\hline Series of cavity flow & $\begin{array}{l}\text { Experimental } \\
\text { technique }\end{array}$ & $\begin{array}{l}\text { The effects of high-frequency, } \\
\text { supersonic microjet injection on } \\
\text { a high-speed cavity flow }\end{array}$ & Specific Mach 1.5 & {$[178]$} \\
\hline cylindrical cavity & $\begin{array}{l}\text { Simulation and } \\
\text { Experimental } \\
\text { investigation }\end{array}$ & $\begin{array}{l}\text { Simulations of pulsed actuators } \\
\text { for high-speed flow control }\end{array}$ & $\begin{array}{l}\text { The parametric investigation will } \\
\text { be effective in changing flow } \\
\text { control results }\end{array}$ & {$[179]$} \\
\hline
\end{tabular}


Table 2. Cont.

\begin{tabular}{|c|c|c|c|c|}
\hline Type of Object & Technique Adopted & Focused Parameter & Limitations & Reference \\
\hline $\begin{array}{l}\text { CD Nozzle with } \\
\text { sudden } \\
\text { expansion duct }\end{array}$ & $\begin{array}{l}\text { CFD approach with } \\
\text { 2D model }\end{array}$ & $\begin{array}{l}\text { Base pressure control } \\
\text { using microjets }\end{array}$ & Limited to two-dimensional model & {$[133,137,147,180]$} \\
\hline Wedge & $\begin{array}{l}\text { CFD approach with } \\
\text { 2D model }\end{array}$ & Aerodynamics flow control & Limited to two-dimensional model & {$[137,138]$} \\
\hline Bluff body & $\begin{array}{l}\text { CFD approach with } \\
\text { 2D model }\end{array}$ & $\begin{array}{l}\text { Splitter plate to control flow and } \\
\text { non-circular cylinder }\end{array}$ & $\begin{array}{l}\text { Limited to a two-dimensional } \\
\text { model }\end{array}$ & {$[137,140-142]$} \\
\hline Airfoil & $\begin{array}{l}\text { CFD approach with } \\
\text { 2D model }\end{array}$ & $\begin{array}{l}\text { Analysis of flows and prediction } \\
\text { of } \mathrm{CH} 10 \text { airfoil for unmanned } \\
\text { aerial vehicle wing design }\end{array}$ & Only simulation & [150] \\
\hline
\end{tabular}

\section{Challenges in the Flow Control Method}

Some major issues can be found when the active flow control method is used:

- Experimental test: One of the major issues during the test is how to reduce the flow disturbances in the connecting pipe from the main settling chamber.

- Instrumentation: With its sensing hole facing the flow, the pitot probe mounted on a rigid $3 \mathrm{D}$ traverse with a resolution of $0.1 \mathrm{~mm}$ was used for pressure measurement. Deficient Reynolds numbers based on the probe diameter significantly influenced the pressures measured by pitot probes. However, this effect is seldom a problem in supersonic streams because a probe of reasonable size will usually have a Reynolds number above 500, which is above the range of troublesome Reynolds numbers.

- Data accuracy: Pressure distribution along the jet centerline with a normal to the tab is difficult to measure and needs a proper location and observation.

- The nozzle calibration: The measured pitot pressure can determine the Mach number by treating the flow through the nozzle to be isentropic, thus leading to the total pressure at the nozzle exit being the same as the settling chamber pressure.

- Simulation: The 2D model was developed in several studies but this can only be suitable when it is uncontrolled or passive controlled. Indeed, a microjet controller needs a 3D model for more accurate results and it is difficult to design, also requiring a supercomputer to simulate/analyze.

- Base pressure: Based on the previous result, the base pressure either increases or decreases when it is controlled and also it varies by varying the nozzle parameter. However, it is critical to increasing the supersonic or hypersonic ranges due to highspeed formation in the setup that has a chance to incur breaks/damages; hence, it needs a very high configured/quality setup for testing.

- Microjet location: It was found that the microjets were located in the PCD of $13 \mathrm{~mm}$ but there is no other location that is reported in the literature; this can be explored well in future studies.

- Soft computing: As compared to DOE, only a few studies are reported with machine learning algorithms and the Fuzzy logic approach. These methods can be explored well in future investigations.

\section{Conclusions}

Throughout this review, the previous work was presented and discussed. The concept of CD nozzle and flow-field was addressed with a fundamental governing equation. The study shows the critical point of view of how researchers utilized the fundamental concepts in the problem solving of high-speed flows, considering active and passive methods. For the passive method, flow, jet, and noise control studies were considered and critically reviewed. Most of the studies in this literature were presented for the active control method; this was the major work of this review. Active control investigation was divided into three powerful techniques: experimental, numerical, and soft computing methods. It was found over the last two decades, the study on active control was done widely with 
an experimental approach. In contrast, the CFD study was conducted very recently but needs improvement on its performance with the three-dimensional approach and the proper finite volume method. Moreover, soft computing is well utilized by the design of experiments methods as compared to machine learning and fuzzy logic. Indeed, no analytical investigation has been made on such a problem. Furthermore, a critical analysis and research gaps in this field were discussed.

In summary, guidelines for scientists seeking to control flow with microjets in any high-speed flow development object were introduced. Descriptions, findings, and analyses of the critical literature on supersonic vehicle applications are included in these guidelines. The categorization can provide a quick overview of the microjet controller study topics. Furthermore, researchers may provide comprehensive viewpoints and benchmarks for particular study topics via the difficulties and possibilities. In brief, these recommendations can assist researchers in developing new ideas, especially in the early phases of this field of study.

Author Contributions: Conceptualization, methodology, investigation, data curation, writingoriginal draft preparation, A.A.; resources, writing-review and editing, supervision, S.A.K. and M.B.; project administration, A.A, S.A.K. and M.B.; funding acquisition, M.B. All authors have read and agreed to the published version of the manuscript.

Funding: This research received no external funding.

Acknowledgments: This research is supported by the Structures and Materials (S\&M) Research Lab of Prince Sultan University. Furthermore, the authors acknowledge the support of Prince Sultan University for paying the article processing charges (APC) of this publication.

Conflicts of Interest: The authors declare no conflict of interest.

\section{References}

1. Khan, S.A.; Rathakrishnan, E. Control of Suddenly Expanded Flows with Micro-Jets. Int. J. Turbo Jet Engines 2003, 20, 63-82. [CrossRef]

2. AAabid, A.; Khan, S.A. Investigation of High-Speed Flow Control from CD Nozzle Using Design of Experiments and CFD Methods. Arab. J. Sci. Eng. 2021, 46, 2201-2230. [CrossRef]

3. Ramanjaneyulu, S. Design and flow analysis of Convergent Divergent nozzle using CFD. Int. J. Res. Appl. Sci. Eng. Technol. 2019, 7, 4020-4029. [CrossRef]

4. Singh, J.; Zerpa, L.E.; Partington, B.; Gamboa, J. Effect of nozzle geometry on critical-subcritical flow transitions. Heliyon 2019, 5, 19. [CrossRef]

5. Rathakrishnan, E. Applied Gas Dynamics; Wiley: Hoboken, NJ, USA, 2019.

6. Greyvenstein, G.P. An implicit method for the analysis of transient flows in pipe networks. Int. J. Numer. Methods Eng. 2001, 53, 1127-1143. [CrossRef]

7. Keir, A.S.; Ives, R.; Hamad, F. CFD analysis of C-D nozzle compared with theoretical \& experimental data. INCAS Bull. 2018, 10, 53-64. [CrossRef]

8. Ferrás, L.L.; Afonso, A.M.; Alves, M.A.; Nóbrega, J.M.; Pinho, F.T. Newtonian and viscoelastic fluid flows through an abrupt 1:4 expansion with slip boundary conditions. Phys. Fluids 2020, 32, 043103. [CrossRef]

9. Poole, R.; Pinho, F.; Alves, M.; Oliveira, P. The effect of expansion ratio for creeping expansion flows of UCM fluids. J. Non Newton. Fluid Mech. 2009, 163, 35-44. [CrossRef]

10. Poole, R.; Alves, M.; Oliveira, P.J.; Pinho, F. Plane sudden expansion flows of viscoelastic liquids. J. Non Newton. Fluid Mech. 2007, 146, 79-91. [CrossRef]

11. Dhinakaran, S.; Oliveira, M.; Pinho, F.; Alves, M. Steady flow of power-law fluids in a 1:3 planar sudden expansion. J. Non Newton. Fluid Mech. 2013, 198, 48-58. [CrossRef]

12. Francisco, A.R.L. Nozzles. J. Chem. Inf. Model. 2013, 53, 1689-1699. [CrossRef]

13. Kumar, R.R.; Devarajan, Y. CFD simulation analysis of two-dimensional convergent-divergent nozzle. Int. J. Ambient. Energy 2018, 41, 1505-1515. [CrossRef]

14. Khan, A.; Aabid, A.; Khan, S.A. CFD Analysis of Convergent-Divergent Nozzle Flow and Base Pressure Control Using Micro-JETS. 2018. Available online: www.sciencepubco.com/index.php/IJET (accessed on 26 July 2021).

15. Khan, S.A.; Rathakrishnan, E. Active Control of Suddenly Expanded Flows from Overexpanded Nozzles. Int. J. Turbo Jet Engines 2002, 19, 119-126. [CrossRef]

16. Raman, R.K.; Dewang, Y.; Raghuwanshi, J. A review on applications of computational fluid dynamics. Int. J. LNCT 2018, 6, 8. 
17. Xu, G.; Luxbacher, K.D.; Ragab, S.; Xu, J.; Ding, X. Computational fluid dynamics applied to mining engineering: A review. Int. J. Min. Reclam. Environ. 2016, 31, 1-25. [CrossRef]

18. Alobaid, F. Computational Fluid Dynamics. Mater. Intern. Struct. 2018, 57, 87-204. [CrossRef]

19. Tapasvi, V.; Gupta, M.S.; Kumaraswamy, T. Designing and Simulating Compressible Flow in a Nozzle. Int. J. Eng. Adv. Technol. 2015, 6, 46-54.

20. Lai, Y.G.; Wu, K. A three-dimensional flow and sediment transport model for free-surface open channel flows on unstructured flexible meshes. Fluids 2019, 4, 18. [CrossRef]

21. Chong, M.S.; Perry, A.E.; Cantwell, B.J. A general classification of three-dimensional flow fields. Phys. Fluids A Fluid Dyn. 1990, 2, 765-777. [CrossRef]

22. Sakaki, K.; Shimizu, Y. Effect of the Increase in the Entrance Convergent Section Length of the Gun Nozzle on the High-Velocity Oxygen Fuel and Cold Spray Process. J. Therm. Spray Technol. 2001, 10, 487-496. [CrossRef]

23. Viswanath, P.R. Aircraft viscous drag reduction using riblets. Prog. Aerosp. Sci. 2002, 38, 571-600. [CrossRef]

24. Ishide, T.; Itazawa, M. Aerodynamic improvement of a delta wing in combination with leading edge flaps. Theor. Appl. Mech. Lett. 2017, 7, 357-361. [CrossRef]

25. Khurana, S.; Suzuki, K.; Rathakrishnan, E. Flow Field around a Blunt-nosed Body with Spike. Int. J. Turbo Jet Engines 2012, 29, 217-221. [CrossRef]

26. Khurana, S.; Suzuki, K. Towards Heat Transfer Control by Aerospikes for Lifting-Body Configuration in Hypersonic Flow at Mach 7. In Proceedings of the 44th AIAA Thermophysics Conference, San Diego, CA, USA, 24-27 June 2013.

27. Khurana, S.; Suzuki, K. Assessment of Aerodynamic Effectiveness for Aerospike Application on Hypothesized Lifting-Body in Hypersonic Flow. In Proceedings of the Fluid Dynamics and Co-Located Conferences, San Diego, CA, USA, 24-27 June 2013; pp. 24-27.

28. Khurana, S.; Suzuki, K.; Rathakrishnan, E. Flow field behavior with Reynolds number variance around a spiked body. Mod. Phys. Lett. B 2016, 30, 1650362. [CrossRef]

29. Sinclair, J.; Cui, X. A theoretical approximation of the shock standoff distance for supersonic flows around a circular cylinder. Phys. Fluids 2017, 29, 026102. [CrossRef]

30. Viswanath, P.R. Passive devices for axisymmetric base drag reduction at transonic speeds. J. Aircr. 1988, 25, 258-262. [CrossRef]

31. Viswanath, P. Flow management techniques for base and afterbody drag reduction. Prog. Aerosp. Sci. 1996, 32, 79-129. [CrossRef]

32. Singh, N.K.; Rathakrishnan, E. Sonic Jet Control with Tabs. Int. J. Turbo Jet Engines 2002, 19, 107-118. [CrossRef]

33. Vijayaraja, K.; Senthilkumar, C.; Elangovan, S.; Rathakrishnan, E. Base Pressure Control with Annular Ribs. Int. J. Turbo Jet Engines 2014, 31, 111-118. [CrossRef]

34. Vikramaditya, N.S.; Viji, M.; Verma, S.B.; Ali, N.; Thakur, D.N. Base Pressure Fluctuations on Typical Missile Configuration in Presence of Base Cavity. J. Spacecr. Rocket. 2018, 55, 335-345. [CrossRef]

35. Kreth, P.A.; Alvi, F.S. Using High-Frequency Pulsed Supersonic Microjets to Control Resonant High-Speed Cavity Flows. AIAA J. 2020, 58, 3378-3392. [CrossRef]

36. Liu, Y.; Zhang, H.; Liu, P. Flow control in supersonic flow field based on micro jets. Adv. Mech. Eng. 2019, 11. [CrossRef]

37. Rathakrishnan, E.; Ramanaraju, O.; Padmanaban, K. Influence of cavities on suddenly expanded flow field. Mech. Res. Commun. 1989, 16, 139-146. [CrossRef]

38. Sethuraman, V.; Khan, S.A. Effect of sudden expansion for varied area ratios at subsonic and sonic flow regimes. Int. J. Energy Environ. Econ. 2016, 24, 99-112.

39. Asadullah, M.; Khan, S.A.; Asrar, W.; Sulaeman, E. Active control of base pressure with counter clockwise rotating cylinder at Mach 2. In Proceedings of the 2017 4th IEEE International Conference on Engineering Technologies and Applied Sciences, Salmabad, Bahrain, 29 November-1 December 2017.

40. Khan, S.A.; Asadullah, M.; Sadhiq, J. Passive Control of Base Drag Employing Dimple in Subsonic Suddenly Expanded Flow. Int. J. Mech. Mechatron. Eng. 2018, 8, 69-74.

41. Gutmark, E.J.; Grinstein, F.F. Flow control with noncircular jets. Annu. Rev. Fluid Mech. 1999, 31, 239-272. [CrossRef]

42. Samimy, M.; Webb, N.; Crawley, M. Excitation of Free Shear-Layer Instabilities for High-Speed Flow Control. AIAA J. 2018, 56, 1770-1791. [CrossRef]

43. Rathakrishnan, E.; Ethirajan, R. AR 4 elliptic jet control with limiting tab. Fluid Dyn. Res. 2017, 50, 025505. [CrossRef]

44. Khan, A.; Kumar, R. Experimental Study and Passive Control of Overexpanded Plug Nozzle Jet. J. Spacecr. Rocket. 2018, 55, 778-782. [CrossRef]

45. Jacksi, K.; Ibrahim, F.; Ali, S. Scholars Journal of Engineering and Technology (SJET). Sch. J. Eng. Technol. 2018, 9523, 49-53. [CrossRef]

46. Akram, S.; Rathakrishnan, E. Control of Supersonic Elliptic Jet with Ventilated Tabs. Int. J. Turbo Jet Engines 2017, 37, 267-283. [CrossRef]

47. Kumar, P.A.; Aileni, M.; Rathakrishnan, E. Impact of tab location relative to the nozzle exit on the shock structure of a supersonic jet. Phys. Fluids 2019, 31, 076104. [CrossRef]

48. Khan, A.; Panthi, R.; Kumar, R.; Ibrahim, S.M. Experimental investigation of the effect of extended cowl on the flow field of planar plug nozzles. Aerosp. Sci. Technol. 2019, 88, 208-221. [CrossRef] 
49. Manigandan, S.; Vijayaraja, K. Flow field and acoustic characteristics of elliptical throat CD nozzle. Int. J. Ambient. Energy 2017, 40, 57-62. [CrossRef]

50. Khan, A.; Akram, S.; Kumar, R. Experimental study on enhancement of supersonic twin-jet mixing by vortex generators. Aerosp. Sci. Technol. 2020, 96, 105521. [CrossRef]

51. Panthi, R.; Krishna, T.V.; Nanda, S.R.; Khan, A.; Kumar, R.; Sugarno, M.I. Experimental Study of Impinging Plug Nozzle Jet Using a Vortex Generator. J. Spacecr. Rocket. 2020, 57, 1414-1418. [CrossRef]

52. Kumar, S.A.; Rathakrishnan, E. Elliptic jet control with triangular tab. Proc. Inst. Mech. Eng. Part G J. Aerosp. Eng. 2017, 231, 1460-1477. [CrossRef]

53. Tam, C.; Tanna, H. Shock associated noise of supersonic jets from convergent-divergent nozzles. J. Sound Vib. 1982, 81, 337-358 [CrossRef]

54. Liu, J.; Ramamurti, R. Numerical Study of Supersonic Jet Noise Emanating from an F404 Nozzle at Model Scale. AIAA Scitech 2019 Forum 2019, 1-28. [CrossRef]

55. Akatsuka, J.; Hromisin, S.; Falcone, J.; McLaughlin, D.K.; Morris, P.J. Mean Flow Measurements in Supersonic Jets with Noise Reduction Devices. AIAA Scitech 2019 Forum 2019, 1-16. [CrossRef]

56. Prasad, C.; Morris, P.J. Unsteady Simulations of Fluid Inserts for Supersonic Jet Noise Reduction. AIAA Scitech 2019 Forum 2019, 1-22. [CrossRef]

57. Gao, J.; Xu, X.; Li, X. Numerical simulation of supersonic twin-jet noise with high-order finite difference scheme. AIAA J. 2018, 56 290-300. [CrossRef]

58. Chen, B.; Wang, Y. Active aerodynamic noise control research for supersonic aircraft cavity by nonlinear numerical simulation. Int. J. Electr. Eng. Educ. 2021. [CrossRef]

59. Zhu, W.; Xiao, Z.; Fu, S. Numerical modeling screen for flow and noise control around tandem cylinders. AIAA J. 2020, 58, 2504-2516. [CrossRef]

60. Patel, T.K. Analysis of Supersonic Jet Noise in the Sideline and Upstream Directions Using the Navier-Stokes Equations. Ph.D. Thesis, University of Florida, Gainesville, FL, USA, 2020.

61. Coombs, J.; Schembri, T.; Zander, A. The effect of hemispherical surface on noise suppression of a supersonic jet. In Proceedings of the Acoustics 2019-Sound Decisions: Moving forward with Acoustics, Mornington Peninsula, Australia, 13-14 May 2019; pp. 1-10.

62. Mondal, K.; Das, S.; Hamada, N.; Abu, A.; Das, S.; Faris, W.; Thiam, H.; Toh, T.; Ahmas, A. An improved narrowband active noise control system without secondary path modelling based on the time domain. Int. J. Veh. Noise Vib. 2019, 15, 110-132. [CrossRef]

63. Berton, J.J.; Huff, D.L.; Geiselhart, K.; Seidel, J. Supersonic Technology Concept Aeroplanes for Environmental Studies. AIAA Scitech 2020 Forum 2020. [CrossRef]

64. Prasad, C.; Morris, P.J. A study of noise reduction mechanisms of jets with fluid inserts. J. Sound Vib. 2020, 476, 115331. [CrossRef]

65. Salehian, S.; Mankbadi, R.R. A review of aeroacoustics of supersonic jets interacting with solid surfaces. AIAA Scitech 2020 Forum 2020, 1-31. [CrossRef]

66. Rahmani, S.K.; Alhawwary, M.A.; Wang, Z.J.; Phommachanh, J.; Hill, C.; Hartwell, B.; Collicott, B.; Swim, J.; Farokhi, S.; Taghavi, R.; et al. Noise Mitigation of a Supersonic Jet Using Shear Layer Swirl. AIAA Scitech 2020 Forum 2020, 1-30. [CrossRef]

67. Horner, C.; Sescu, A.; Afsar, M.; Collins, E.; Azarpeyvand, M. Passive Noise Control Strategies for Jets Exhausting over Flat Surfaces: An LES Study. AIAA Aviation 2020 Forum 2020, 1-17. [CrossRef]

68. Prasad, C.; Morris, P.J. Steady active control of noise radiation from highly heated supersonic jets. J. Acoust. Soc. Am. 2021, 149, 1306-1317. [CrossRef] [PubMed]

69. Pourhashem, H.; Kumar, S.; Kalkhoran, I.M. Flow field characteristics of a supersonic jet influenced by downstream microjet fluidic injection. Aerosp. Sci. Technol. 2019, 93, 105281. [CrossRef]

70. Li, B.; Ye, C.-C.; Wan, Z.-H.; Liu, N.-S.; Sun, D.-J.; Lu, X.-Y. Noise control of subsonic flow past open cavities based on porous floors. Phys. Fluids 2020, 32, 125101. [CrossRef]

71. Martin, R.; Soria, M.; Rodriguez, I.; Lehmkuhl, O. On the Flow and Passive Noise Control of an Open Cavity at Re = 5000. Flow Turbul. Combust. 2021, 1-26. [CrossRef]

72. Ye, C.C.; Zhang, P.J.Y.; Wan, Z.H.; Sun, D.J.; Lu, X.Y. Numerical investigation of the bevelled effects on shock structure and screech noise in planar supersonic jets. Phys. Fluids 2020, 32. [CrossRef]

73. Su, Z.; Liu, E.; Xu, Y.; Xie, P.; Shang, C.; Zhu, Q. Flow field and noise characteristics of manifold in natural gas transportation station. Oil Gas Sci. Technol. Rev. l'IFP 2019, 74, 70. [CrossRef]

74. Wei, X.; Mariani, R.; Chua, L.; Lim, H.D.; Lu, Z.; Cui, Y.; New, T.H. Mitigation of under-expanded supersonic jet noise through stepped nozzles. J. Sound Vib. 2019, 459, 1-18. [CrossRef]

75. Coombs, J.; Zander, A.; Schembri, T. Influence of a Hemispherical Noise Reduction Reflector on Transonic Jet Flows. In Proceedings of the 22nd Australasian Fluid Mechanics Conference AFMC2020, Brisbane, Australia, 7-10 December 2020.

76. Cuppoletti, D.; Gutmark, E.J.; Hafsteinsson, H.E.; Eriksson, L.-E. Elimination of Shock Associated Noise in Supersonic Jets by Destructive Wave Interference. AIAA J. 2018, 57, 720-734. [CrossRef]

77. Kumar, P.A.; Kumar, S.M.A.; Mitra, A.S.; Rathakrishnan, E. Empirical scaling analysis of supersonic jet control using steady fluidic injection. Phys. Fluids 2019, 31, 056107. [CrossRef] 
78. Mancini, S.; Kolb, A.; Gonzalez-Martino, I.; Casalino, D. Effects of wall modifications on pressure oscillations in high-subsonic and supersonic flows over rectangular cavities. In Proceedings of the 25th AIAA/CEAS Aeroacoustics Conference, Delft, The Netherlands, 20-23 May 2019; pp. 1-20. [CrossRef]

79. Xiansheng, W.; Dangguo, Y.; Jun, L.; Fangqi, Z. Control of Pressure Oscillations Induced by Supersonic Cavity Flow. AIAA J. 2020, 58, 2070-2077. [CrossRef]

80. Robertson, G.; Kumar, R. Effects of a Generic Store on Cavity Resonance at Supersonic Speeds. AIAA J. 2020, 58, 4426-4437. [CrossRef]

81. Prasad, C.; Morris, P. Effect of fluid injection on turbulence and noise reduction of a supersonic jet. Philos. Trans. R. Soc. A Math. Phys. Eng. Sci. 2019, 377, 20190082. [CrossRef] [PubMed]

82. Anureka, R.; Srinivasan, K. Passive control of pipe-jet noise using trailing-edge castellations. Appl. Acoust. 2020, 170, 107516. [CrossRef]

83. Khan, S.A.; Rathakrishnan, E. Active Control of Suddenly Expanded Flows from Underexpanded Nozzles. Int. J. Turbo Jet Engines 2004, 21, 233-254. [CrossRef]

84. Khan, S.A.; Rathakrishnan, E. Control of Suddenly Expanded Flows from Correctly Expanded Nozzles. Int. J. Turbo Jet Engines 2004, 21, 255-278. [CrossRef]

85. Khan, S.A.; Rathakrishnan, E. Active Control of Suddenly Expanded Flows from Underexpanded Nozzles-Part II. Int. J. Turbo Jet Engines 2005, 22, 163-183. [CrossRef]

86. Khan, S.; Rathakrishnan, E. Control of suddenly expanded flow. Aircr. Eng. Aerosp. Technol. 2006, 78, 293-309. [CrossRef]

87. Khan, S.A.; Rathakrishnan, E. Nozzle Expansion Level Effect on Suddenly Expanded Flow. Int. J. Turbo Jet Engines 2006, 23, 233-258. [CrossRef]

88. Rehman, S.; Khan, S.A. Control of base pressure with micro-jets: Part I. Aircr. Eng. Aerosp. Technol. 2008, 80, 158-164. [CrossRef]

89. Baig, M.A.A.; Al-Mufadi, F.; Khan, S.A.; Rathakrishnan, E. Control of Base Flows with Micro Jets Control of Base Flows with Micro Jets. Int. J. Turbo Jet Engines 2011, 28, 59-69. [CrossRef]

90. Biag, M.A.A.; Khan, S.A.; Rathakrishnan, E. Active control of base pressure in suddenly expanded flow for area ratio 4.84 . Int. J. Eng. Sci. Technol. 2012, 4, 1892-1902.

91. Kostic, O.; Stefanović, Z.; Kostič, I.; Olivera, K.; Zoran, S.; Ivan, K. CFD modeling of supersonic airflow generated by 2D nozzle with and without an obstacle at the exit section. FME Trans. 2015, 43, 107-113. [CrossRef]

92. Fharukh, M.; Asadullah, M.; Khan, S.A. Experimental Study of Suddenly Expanded Flow from Correctly Expanded Nozzles. ARPN J. Eng. Appl. Sci. 2016, 11, 10041-10047.

93. Khan, S.A.; Aabid, A.; Chaudhary, Z.I. Influence of control mechanism on the flow field of duct at mach 1.2 for area ratio 2.56 . Int. J. Innov. Technol. Explor. Eng. 2019, 8, 1135-1138. [CrossRef]

94. Chaudhary, Z.I.; Shinde, V.B.; Khan, S.A. Investigation of base flow for an axisymmetric suddenly expanded nozzle with micro JET. Int. J. Eng. Technol. 2018, 7, 236-242. [CrossRef]

95. Ahmed, F.; Khan, S.A. Investigation of efficacy of low length-to-diameter ratio and nozzle pressure ratio on base pressure in an abruptly expanded flow. In Proceedings of the MATEC Web of Conferences, Chennai, India, 31 July 2018; Volume 01004, pp. 1-6. [CrossRef]

96. Khan, S.A.; Asadullah, M.; Jalaluddeen, A.; Baig, M.A. Flow Control with Aerospike behind Bluff Body. Int. J. Mech. Prod. Eng. Res. Dev. 2018, 8, 1001-1008.

97. Khan, S.A.; Al Robaian, A.A.; Asadullah, M.; Khan, A.M. Grooved Cavity as a Passive Controller behind Backward Facing Step. J. Adv. Res. Fluid Mech. Therm. Sci. 2019, 53, 185-193.

98. Khan, S.A.; Alrobaian, A.A.; Asadullah, M. Threaded Spikes for Bluff Body Base Flow Control. J. Adv. Res. Fluid Mech. Therm. Sci. 2019, 2, 194-203.

99. Khan, S.A.; Rathakrishnan, E. Active Control of Base Pressure in Supersonic Regime. J. Inst. Eng. Aerosp. Eng. J. 2006, 87, 1-10.

100. AAabid Fharukh, A.; Sher Afghan, K. Experimental Investigation of Wall Pressure Distribution in a Suddenly Expanded Duct from a Convergent-Divergent Nozzle. In Proceedings of the 2019 6th IEEE International Conference on Engineering Technologies and Applied Sciences (ICETAS), Kuala Lumpur, Malaysia, 20-21 December 2019; p. 6. [CrossRef]

101. Khan, S.A.; Aabid, A.; Mokashi, I.; Ahmed, Z. Effect of Micro Jet Control on the Flow Filed of the Duct at Mach 1.5. Int. J. Recent Technol. Eng. 2019, 8, 1758-1762. [CrossRef]

102. Khan, S.A.; Mokashi, I.; Aabid, A.; Faheem, M. Experimental Research on Wall Pressure Distribution in C-D Nozzle at Mach number 1.1 for Area Ratio 3.24. Int. J. Recent Technol. Eng. 2019, 8, 971-975. [CrossRef]

103. Faheem, M.; Kareemullah, M.; Aabid, A.; Mokashi, I.; Khan, S.A. Experiment on of nozzle flow with sudden expansion at mach 1.1. Int. J. Recent Technol. Eng. 2019, 8, 1769-1775. [CrossRef]

104. Akhtar, M.N.; Bakar, E.A.; Aabid, A.; Khan, S.A. Effects of micro jets on the flow field of the duct with sudden expansion. Int. J. Innov. Technol. Explor. Eng. 2019, 8, 636-640. [CrossRef]

105. Azami, M.H.; Faheem, M.; Aabid, A.; Mokashi, I.; Khan, S.A. Experimental Research of Wall Pressure Distribution and Effect of Micro Jet at Mach 1.5. Int. J. Recent Technol. Eng. 2019, 8, 1000-1003.

106. Aabid, A.; Khan, S.A. Determination of wall pressure flows at supersonic Mach numbers. Mater. Today Proc. 2021, 38, $2347-2352$. [CrossRef] 
107. Saleel, A.; Baig, M.A.A.; Khan, S.A. Experimental Investigation of the Base Flow and Base Pressure of Sudden Expansion Nozzle. IOP Conf. Ser. Mater. Sci. Eng. 2018, 370, 012052. [CrossRef]

108. Khan, S.A.; Ahmed, Z.; Aabid, A.; Mokashi, I. Experimental research on flow development and control effectiveness in the duct at high speed. Int. J. Recent Technol. Eng. 2019, 8, 1763-1768. [CrossRef]

109. Azami, M.H.; Faheem, M.; Aabid, A.; Mokashi, I.; Khan, S.A. Inspection of Supersonic Flows in a CD Nozzle using Experimental Method. Int. J. Recent Technol. Eng. 2019, 8, 996-999.

110. Akhtar, M.N.; Bakar, E.A.; Aabid, A.; Khan, S.A. Control of CD nozzle flow using microjets at mach 2.1. Int. J. Innov. Technol. Explor. Eng. 2019, 8, 631-635. [CrossRef]

111. Aabid, A.; Khan, S.A. Studies on Flows Development in a Suddenly Expanded Circular Duct at Supersonic Mach Numbers. Int. J. Heat Technol. 2021, 38, 185-194. [CrossRef]

112. Aabid, A.; Khan, S.A.; Baig, M.A.A.; Reddy, A.R. Investigation of Flow Growth in aDuct Flowsfor Higher Area Ratio. IOP Conf. Ser. Mater. Sci. Eng. 2021, 1057, 10. [CrossRef]

113. Aabid, A.; Khan, S.A.; Baig, M.A.A.; Rao, K.S. Effect of Control on the Duct Flow at High Mach Numbers. IOP Conf. Ser. Mater. Sci. Eng. 2021, 1057, 9. [CrossRef]

114. Kumar, A.A.; Manoj, N.; Onkar, A.K.; Manjuprasad, M. Fluid-Structure Interaction Analysis of a Cropped Delta Wing. Procedia Eng. 2016, 144, 1205-1212. [CrossRef]

115. Ali, A.; Neely, A.; Young, J.; Blake, B.; Lim, J.Y. Numerical Simulation of Fluidic Modulation of Nozzle Thrust. In Proceedings of the 17th Australasian Fluid Mechanics Conference, Auckland, New Zeeland, 5-9 December 2010; pp. 5-8.

116. Kumar, G.M.; Fernando, D.X.; Kumar, R.M. Design and Optimization of De Lavel Nozzle to Prevent Shock Induced Flow Separation. Adv. Aerosp. Sci. Appl. 2013, 3, 119-124.

117. Shariatzadeh, O.J.; Abrishamkar, A.; Jafari, A.J. Computational Modeling of a Typical Supersonic Converging-Diverging Nozzle and Validation by Real Measured Data. J. Clean Energy Technol. 2015, 3, 220-225. [CrossRef]

118. Su, L. CFD Simulation and Shape Optimization of Supersonic Ejectors for Refrigeration and Desalination Applications. Master's Thesis, Washington University, St. Louis, MO, USA, 2015.

119. SA Khan MMohiuddin AS, C.; Fharukh, G.M. Investigation of the Effects of Nozzle Exit Mach number and Nozzle Pressure Ratio on Axisymmetric Flow through Suddenly Expanded Nozzles. Int. J. Eng. Adv. Technol. 2019, 8, 570-578.

120. Cai, Y.; Liu, Z.; Shi, Z.; Song, Q.; Wan, Y. Residual surface topology modeling and simulation analysis for micro-machined nozzle. Int. J. Precis. Eng. Manuf. 2015, 16, 157-162. [CrossRef]

121. Belega, B.-A.; Nguyen, T.D. Analysis of Flow in Convergent-Divergent Rocket Engine Nozzle Using Computational Fluid Dynamics. In Proceedings of the International Conference of Science Paper AFASES, Brasov, Romania, 28-30 May 2015 ; p. 6.

122. Patel, M.S.; Mane, S.D.; Raman, M. Concepts and CFD Analysis of De-Laval Nozzle. Int. J. Mech. Eng. Technol. 2016, 7, 221-240.

123. Mouli, C.S.; Vardhan, C.N.; Chowdary, G.V.; Jeevan, P. Aerodynamic Design and Performance of Nozzle with Different Mach Numbers Using CFD Analysis. IRJET 2017, 9, 20-27.

124. Pathan, K.A.; Khan, S.A.; Dabeer, P.S. CFD Analysis of Effect of Flow and Geometry Parameters on Thrust Force Created by Flow from Nozzle. In Proceedings of the 2nd International Conference for Convergence in Technology (I2CT) CFD, Mumbai, India, 7-9 April 2017; pp. 1121-1125.

125. Pathan, K.A.; Khan, S.A.; Dabeer, P.S. CFD analysis of effect of area ratio on suddenly expanded flows. In Proceedings of the 2017 2nd International Conference for Convergence in Technology (I2CT), Mumbai, India, 7-9 April 2017; pp. 1192-1198.

126. Pathan, K.A.; Khan, S.A.; Dabeer, P.S. CFD analysis of effect of Mach number, area ratio and nozzle pressure ratio on velocity for suddenly expanded flows. In Proceedings of the 2017 2nd International Conference for Convergence in Technology (I2CT) CFD, Mumbai, India, 7-9 April 2017; pp. 1104-1110.

127. Ahmed, K.; Dabeer, P.S.; Afghan, S. Optimization of area ratio and thrust in suddenly expanded fl ow at supersonic Mach numbers. Case Stud. Therm. Eng. 2018, 12, 696-700. [CrossRef]

128. Moorthy, C.; Srinisas, V.; Prasad, V.; Vanaja, T. Computational Analysis of a Cd Nozzle with 'Sed' for a Rocket Air Ejector in Space Applications. Int. J. Mech. Prod. Eng. Res. Dev. 2017, 7, 53-60. Available online: http://tjprc.org/view-archives.php (accessed on 26 July 2021).

129. Arun, K.; Tiwari, S.; Mani, A. Three-dimensional numerical investigations on rectangular cross-section ejector. Int. J. Therm. Sci. 2017, 122, 257-265. [CrossRef]

130. Zhang, G.; Kim, H.D. Theoretical and numerical analysis on choked multiphase flows of gas and solid particle through a convergent-divergent nozzle. J. Comput. Multiph. Flows 2017, 10, 19-32. [CrossRef]

131. Pilon, A.R.; McLaughlin, D.K.; Morris, P.J.; Powers, R.W. Design and Analysis of a Supersonic Jet Noise Reduction Concept. J. Aircr. 2014, 54, 1705-1717. [CrossRef]

132. Khan, S.A.; Aabid, A.; Ghasi, F.A.M.; Al-Robaian, A.A.; Alsagri, A.S. Analysis of Area Ratio in a CD Nozzle with Suddenly Expanded Duct using CFD Method. CFD Lett. 2019, 11, 61-71.

133. Fharukh, A.G.M.; Alrobaian, A.A.; Aabid, A.; Khan, S.A. Numerical Analysis of Convergent-Divergent Nozzle Using Finite Element Method. Int. J. Mech. Prod. Eng. Dev. 2018, 8, 373-382. Available online: www.tjprc.org (accessed on 26 July 2021).

134. Khan, S.A.; Aabid, A.; Baig, M.A.A. CFD analysis of cd nozzle and effect of nozzle pressure ratio on pressure and velocity for suddenly expanded flows. Int. J. Mech. Prod. Eng. Res. Dev. 2018, 8, 1147-1158. [CrossRef] 
135. Khan, S.A.; Aabid, A.; Saleel, C.A. Influence of Micro Jets on the Flow Development in the Enlarged Duct at Supersonic Mach number. Int. J. Mech. Mechatron. Eng. 2019, 19, 70-82.

136. Aabid, A.; Khan, A.; Mazlan, N.M.; Ismail, M.A.; Akhtar, M.N.; Khan, S.A. Numerical Simulation of Suddenly Expanded Flow at Mach 2.2. Int. J. Eng. Adv. Technol. 2019, 8, 452-457.

137. Sajali, M.F.M.; Aabid, A.; Khan, S.A.; Fharukh, A.; Sulaeman, E. Numerical Investigation of Flow Field of a Non-Circular Cylinder. CFD Lett. 2019, 11, 37-49.

138. Khan, S.A.; Aabid, A.; Ahmed, S. CFD Simulation with Analytical and Theoretical Validation of Different Flow Parameters for the Wedge at Supersonic Mach Number. Int. J. Mech. Mechatron. Eng. 2019, 19, 170-177.

139. Khan, S.A.; Aabid, A.; Mokashi, I.; Al-Robaian, A.A.; Alsagri, A.S. Optimization of Two-dimensional Wedge Flow Field at Supersonic Mach Number. CFD Lett. 2019, 11, 80-97.

140. Sajali, M.F.M.; Ashfaq, S.; Aabid, A.; Khan, S.A. Simulation of Effect of Various Distances between Front and Rear Body on Drag of a Non-Circular Cylinder. J. Adv. Res. Fluid Mech. Therm. Sci. 2019, 62, 53-65.

141. Aabid, A.; Afifi, A.; Ali, F.A.G.M.; Akhtar, M.N.; Khan, S.A. CFD Analysis of Splitter Plate on Bluff Body. CFD Lett. 2019, 11, 5-38.

142. Afifi, A.; Aabid, A.; Khan, S.A. Numerical investigation of splitter plate effect on bluff body using finite volume method. Mater. Today Proc. 2021, 38, 2181-2190. [CrossRef]

143. Zhang, D.; Tan, J.; Yao, X. Numerical investigation on splitter plate jet assisted mixing in supersonic flow. Acta Astronaut. 2021. [CrossRef]

144. Kharulaman, L.; Aabid, A.; Ahmed, F.; Mehaboobali, G.; Khan, S.A. Research on Flows for NACA 2412 Airfoil using Computational Fluid Dynamics Method. Int. J. Eng. Adv. Technol. 2019, 9, 5450-5456. [CrossRef]

145. Aabid, A.; Nabilah, L.; Khairulaman, B.; Khan, S.A. Analysis of Flows and Prediction of CH10 Airfoil for Unmanned Arial Vehicle Wing Design. Adv. Aircr. Spacecr. Sci. 2021, 2, 24. [CrossRef]

146. Khan, S.A.; Fatepurwala, M.A.; Pathan, K.N.; Dabeer, P.S.; Baig, M.A.A. CFD Analysis of Human Powered Submarine to Minimize Drag. Int. J. Mech. Prod. Eng. Res. Dev. 2018, 8, 1057-1066. [CrossRef]

147. Akhtar, M.N.; Bakar, E.A.; Aabid, A.; Khan, S.A. Numerical Simulations of a CD Nozzle and the Influence of the Duct Length. Int. J. Innov. Technol. Explor. Eng. 2019, 8, 622-630.

148. Aabid, A.; Chaudhary, Z.I.; Khan, S.A. Modelling and Analysis of Convergent Divergent Nozzle with Sudden Expansion Duct using Finite Element Method. J. Adv. Res. Fluid Mech. Therm. Sci. J. 2019, 63, 34-51.

149. Fischer, R.A.; Yates, F. Statistical Methods for Research Workers; Oliver and Boyd: Edinburgh, UK, 1935; pp. $241-271$.

150. Montgomery, D.C. Design and Analysis of Experiments, 8th ed.; John Wiley \& Sons, Inc.: Hoboken, NJ, USA, 2013.

151. Quadros, J.D.; Khan, S.A.; Antony, A.J. Investigation of effect of process parameters on suddenly Expanded flows through an axi-symmetric nozzle for different Mach Numbers using Design of Experiments. IOP Conf. Ser. Mater. Sci. Eng. 2017, 184, 012005. [CrossRef]

152. Quadros, J.D.; Khan, S.A.; Antony, A.J. Base Pressure Behaviour in a Suddenly Expanded Duct at Supersonic Mach Number Regimes using Taguchi Design of Experiments. Mech. Mech. Eng. 2018, 22, 1077-1098. [CrossRef]

153. Quadros, J.; Khan, S.A.; Antony, A.J. Study of Effect of Flow Parameters on Base Pressure in a Suddenly Expanded Duct at Supersonic Mach Number Regimes using CFD and Design of Experiments. J. Appl. Fluid Mech. 2018, 11, 483-496. [CrossRef]

154. Quadros, J.D.; Khan, S.A.; Anthony, J.A. Modelling of Suddenly Expanded Flow Process in Supersonic Mach Regime using Design of Experiments and Response Surface Methodology. J. Comput. Appl. Mech. 2018, 49, 149-160.

155. Quadros, J.D.; Khan, S.; Antony, A. Study of base pressure behavior in a suddenly expanded duct at supersonic mach number regimes using statistical analysis. J. Appl. Math. Comput. Mech. 2018, 17, 59-72. [CrossRef]

156. Al-khalifah, T.; Aabid, A.; Khan, S.A.; Azami, M.H.B.; Baig, M. Response surface analysis of the nozzle flow parameters at supersonic flow through microjets. Aust. J. Mech. Eng. 2021, 13, 1-15. [CrossRef]

157. Majil, D.D.; Poojitha, A.; Devi, G. Computational Study on Optimization of Rocket Nozzle. Master's Thesis, University of Southampton, Southampton, UK, 2016; pp. 8-13.

158. Quadros, J.; Khan, S.; Anthony, J.A. Predictive modeling of suddenly expanded flow process in the Supersonic Mach number regime using response surface methodology. Int. J. Recent Res. Asp. 2018, 49, 149-160.

159. Al-khalifah, T.; Aabid, A.; Khan, S.A. Regression Analysis of Flow Parameters at High Mach Numbers. Solid State Technol. 2020, $63,5473-5488$.

160. Jagannath, R.; Naresh, N.G.; Pandey, K.M. Studies on Pressure Loss in Sudden Expansion in Flow through Nozzles: A Fuzzy Logic Approach. ARPN J. Eng. Appl. Sci. 2007, 2, 50-61.

161. Pandey, K.M.; Kumar, A. Studies on Base Pressure in Suddenly Expanded Circular Ducts: A Fuzzy Logic Approach. Int. J. Eng. Technol. 2010, 2, 379-386. [CrossRef]

162. Pandey, K.M.; Kumar, S.; Kalita, J.P. Wall static pressure variation in sudden expansion in cylindrical ducts with supersonic flow: A fuzzy logic approach. Int. J. Soft Comput. Eng. 2012, 2, 237-242. [CrossRef]

163. Quadros, J.D.; Khan, S.A.; Sapkota, S.; Vikram, J.; Prashanth, T. On Recirculation Region Length of Suddenly Expanded Supersonic Flows, Using CFD and Fuzzy Logic. Int. J. Comut. Fluid Dyn. 2020, 1-16. [CrossRef]

164. Efe, M.Ö.; Debiasi, M.; Yan, P.; Özbay, H.; Samimy, M. Neural network-based modelling of subsonic cavity flows. Int. J. Syst. Sci. 2008, 39, 105-117. [CrossRef] 
165. De Mattos Secco, B.S.; Ney, R. Artificial neural networks to predict aerodynamic coefficients of transport airplanes. Aircr. Eng. Aerosp. Technol. 2017, 89, 19-39. [CrossRef]

166. Afzal, A.; Aabid, A.; Khan, A.; Khan, S.A.; Rajak, U.; Verma, T.N.; Kumar, R. Response surface analysis, clustering, and random forest regression of pressure in suddenly expanded high-speed aerodynamic flows. Aerosp. Sci. Technol. 2020, 107, 106318. [CrossRef]

167. Afzal, A.; Khan, S.A.; Islam, M.T.; Jilte, R.D.; Khan, A.; Soudagar, M.E.M. Investigation and back-propagation modeling of base pressure at sonic and supersonic Mach numbers. Phys. Fluids 2020, 32. [CrossRef]

168. Uzun, A.; Solomon, J.T.; Foster, C.H.; Oates, W.S.; Hussaini, M.Y.; Alvi, F.S. Flow Physics of a Pulsed Microjet Actuator for High-Speed Flow Control. AIAA J. 2013, 51, 2894-2918. [CrossRef]

169. Da, X.; Fan, Z.; Fan, J.; Zeng, L.; Rui, W.; Zhou, R. Microjet flow control in an ultra-compact serpentine inlet. Chin. J. Aeronaut. 2015, 28, 1381-1390. [CrossRef]

170. Kreth, P.; Alvi, F. Microjet based active flow control on a fixed wing UAV. J. Flow Control. Meas. Vis. 2010, 2, 32-41. [CrossRef]

171. Alvi, F.S.; Elavarasan, R.; Shih, C.; Garg, G.; Krothapalli, A. Control of supersonic impinging jet flows using microjets. Fluids 2000 Conf. Exhib. 2000, 1-8. [CrossRef]

172. Ali, M.Y.; Arora, N.; Topolski, M.; Alvi, F.S.; Solomon, J.T. Properties of Resonance Enhanced Microjets in Supersonic Crossflow. AIAA J. 2017, 55, 1075-1081. [CrossRef]

173. Tebbiche, H.; Boutoudj, M.S. Active flow control by micro-blowing and effects on aerodynamic performances. Ahmed body and NACA 0015 airfoil. Int. J. Fluid Mech. Res. 2021, 48, 29-46. [CrossRef]

174. Hosseini, S.S.; Cooperman, A.; van Dam, C.P.; Pandya, S.A. Microjet Configuration Sensitivities for Active Flow Control on Multi-Element High-Lift Systems. J. Aircr. 2021, 1-19. [CrossRef]

175. Hosseini, S.S.; van Dam, C.P.; Pandya, S.A. Surface-Normal Active Flow Control for Lift Enhancement and Separation Mitigation for High-Lift Common Research Model. In Proceedings of the AIAA Scitech 2021 Forum, Vitual Event, 11-15, 19-21 January 2021; Available online: https:/ / arc.aiaa.org/doi/book/10.2514/MSCITECH21 (accessed on 26 July 2021).

176. Verma, S.B.; Manisankar, C. Control of Compression-Ramp-Induced Interaction with Steady Microjets. AIAA J. 2019, 57, $2892-2904$. [CrossRef]

177. Burrows, T.J.; Vukasinovic, B.; Glezer, A. Flow Dynamics Effected by Active Flow Control in an Offset Diffuser. In Proceedings of the AIAA Aviation Forum, Atlanta, GA, USA, 25-29 June 2018; pp. 1-13. [CrossRef]

178. Kreth, P.A. The Effects of High-Frequency, Supersonic Microjet Injection on a High-Speed Cavity Flow. In Proceedings of the 55th AIAA Aerospace Sciences Meeting, Grapevine, TX, USA, 9-13 January 2017. [CrossRef]

179. Uzun, A.; Foster, C.H.; Solomon, J.T.; Oates, W.S.; Hussaini, M.Y.; Alvi, F.S. Simulations of pulsed actuators for high-speed flow control. In Proceedings of the 17th AIAA/CEAS Aeroacoustics Conference (32nd AIAA Aeroacoustics Conference), Portland, OR, USA, 5-8 June 2018. [CrossRef]

180. Afghan, S.; Mohamed, O.; Aabid, A. CFD analysis of compressible flows in a convergent-divergent nozzle. Mater. Today Proc. 2021. [CrossRef] 